\title{
Evolution of trace gases and particles emitted by a chaparral fire in California
}

\author{
S. K. Akagi ${ }^{1}$, J. S. Craven ${ }^{2}$, J. W. Taylor ${ }^{3}$, G. R. McMeeking ${ }^{3,}{ }^{*}$, R. J. Yokelson ${ }^{1}$, I. R. Burling ${ }^{1}$, S. P. Urbanski ${ }^{4}$, \\ C. E. Wold ${ }^{4}$, J. H. Seinfeld ${ }^{2}$, H. Coe ${ }^{3}$, M. J. Alvarado ${ }^{5}$, and D. R. Weise ${ }^{6}$ \\ ${ }^{1}$ University of Montana, Department of Chemistry, Missoula, MT, USA \\ ${ }^{2}$ California Institute of Technology, Division of Chemistry and Chemical Engineering, Pasadena, CA, USA \\ ${ }^{3}$ University of Manchester, Centre for Atmospheric Science, Manchester, UK \\ ${ }^{4}$ United States Forest Service, Fire Sciences Laboratory, Missoula, MT, USA \\ ${ }^{5}$ Atmospheric and Environmental Research (AER), Lexington, MA, USA \\ ${ }^{6}$ USDA Forest Service, Pacific Southwest Research Station, Forest Fire Laboratory, Riverside, CA, USA \\ *now at: Department of Atmospheric Science, Colorado State University, Fort Collins, USA
}

Correspondence to: R. J. Yokelson (bob.yokelson@umontana.edu)

Received: 2 June 2011 - Published in Atmos. Chem. Phys. Discuss.: 8 August 2011

Revised: 27 December 2011 - Accepted: 20 January 2012 - Published: 7 February 2012

\begin{abstract}
Biomass burning (BB) is a major global source of trace gases and particles. Accurately representing the production and evolution of these emissions is an important goal for atmospheric chemical transport models. We measured a suite of gases and aerosols emitted from an 81 hectare prescribed fire in chaparral fuels on the central coast of California, US on 17 November 2009. We also measured physical and chemical changes that occurred in the isolated downwind plume in the first $\sim 4 \mathrm{~h}$ after emission. The measurements were carried out onboard a Twin Otter aircraft outfitted with an airborne Fourier transform infrared spectrometer (AFTIR), aerosol mass spectrometer (AMS), single particle soot photometer (SP2), nephelometer, $\mathrm{LiCor} \mathrm{CO}_{2}$ analyzer, a chemiluminescence ozone instrument, and a wingmounted meteorological probe. Our measurements included: $\mathrm{CO}_{2} ; \mathrm{CO} ; \mathrm{NO}_{\mathrm{x}} ; \mathrm{NH}_{3}$; non-methane organic compounds; organic aerosol (OA); inorganic aerosol (nitrate, ammonium, sulfate, and chloride); aerosol light scattering; refractory black carbon (rBC); and ambient temperature, relative humidity, barometric pressure, and three-dimensional wind velocity. The molar ratio of excess $\mathrm{O}_{3}$ to excess $\mathrm{CO}$ in the plume $\left(\Delta \mathrm{O}_{3} / \Delta \mathrm{CO}\right)$ increased from $-5.13( \pm 1.13) \times 10^{-3}$ to $10.2( \pm 2.16) \times 10^{-2}$ in $\sim 4.5 \mathrm{~h}$ following smoke emission. Excess acetic and formic acid (normalized to excess $\mathrm{CO}$ ) increased by factors of $1.73 \pm 0.43$ and $7.34 \pm 3.03$ (respectively) over the same time since emission. Based on the rapid decay of $\mathrm{C}_{2} \mathrm{H}_{4}$ we infer an in-plume average $\mathrm{OH}$
\end{abstract}

concentration of $5.27( \pm 0.97) \times 10^{6} \mathrm{molec} \mathrm{cm}^{-3}$, consistent with previous studies showing elevated $\mathrm{OH}$ concentrations in biomass burning plumes. Ammonium, nitrate, and sulfate all increased over the course of $4 \mathrm{~h}$. The observed ammonium increase was a factor of $3.90 \pm 2.93$ in about $4 \mathrm{~h}$, but accounted for just $\sim 36 \%$ of the gaseous ammonia lost on a molar basis. Some of the gas phase $\mathrm{NH}_{3}$ loss may have been due to condensation on, or formation of, particles below the AMS detection range. $\mathrm{NO}_{\mathrm{x}}$ was converted to PAN and particle nitrate with PAN production being about two times greater than production of observable nitrate in the first $\sim 4 \mathrm{~h}$ following emission. The excess aerosol light scattering in the plume (normalized to excess $\mathrm{CO}_{2}$ ) increased by a factor of $2.50 \pm 0.74$ over $4 \mathrm{~h}$. The increase in light scattering was similar to that observed in an earlier study of a biomass burning plume in Mexico where significant secondary formation of OA closely tracked the increase in scattering. In the California plume, however, $\triangle \mathrm{OA} / \Delta \mathrm{CO}_{2}$ decreased sharply for the first hour and then increased slowly with a net decrease of $\sim 20 \%$ over $4 \mathrm{~h}$. The fraction of thickly coated $\mathrm{rBC}$ particles increased up to $\sim 85 \%$ over the $4 \mathrm{~h}$ aging period. Decreasing OA accompanied by increased scattering/particle coating in initial aging may be due to a combination of particle coagulation and evaporation processes. Recondensation of species initially evaporated from the particles may have contributed to the subsequent slow rise in OA. We compare our results to observations from other plume aging studies 
and suggest that differences in environmental factors such as smoke concentration, oxidant concentration, actinic flux, and $\mathrm{RH}$ contribute significantly to the variation in plume evolution observations.

\section{Introduction}

Biomass burning (BB) is the largest global source of primary, fine carbonaceous particles; the second largest source of trace gases; and a key element of the carbon cycle (Crutzen and Andreae, 1990; Fearnside et al., 1993; Bond et al., 2004; Akagi et al., 2011). Globally, dry season deforestation and savanna fires in the tropics are the most dominant, and most studied, type of open burning (Yokelson et al., 2003a; van der Werf et al., 2010). However, the comparatively smaller amount of BB that occurs year-round in the contiguous US is a prominent domestic source of gas and particle emissions. These fires may be prescribed or ignited naturally. Prescribed burning is a significant fraction of US BB and it is used to restore or maintain the natural, beneficial role of fire in many terrestrial ecosystems; reduce fire risk by consuming accumulated wildland fuels under preferred weather conditions; and accomplish other land management objectives (Biswell, 1989; Hardy et al., 2001; Carter and Foster, 2004; Wiedinmyer and Hurteau, 2010). These burns are often recurrent, sometimes near populated areas, and despite being controlled may occasionally have negative air quality impacts. Together, wild and prescribed fires are thought to produce about one-third of the total $\mathrm{PM}_{2.5}$ (particle mass with aerodynamic diameter $<2.5 \mu \mathrm{m}$ ) in the US (Watson, 2002; Park et al., 2007). The particles can impact local to regional air quality, health, and visibility (McMeeking et al., 2006). In addition, fires can influence regional levels of ozone $\left(\mathrm{O}_{3}\right)$, which is an air toxic (Pfister et al., 2006). Large areas of the US commonly have $\mathrm{O}_{3}$ mixing ratios not far below the US national ambient $\mathrm{O}_{3}$ air quality standard (75 ppb 8-h average). Thus, in these areas even modest production of $\mathrm{O}_{3}$ in a smoke plume can potentially lead to $\mathrm{O}_{3}$ levels that exceed air quality criteria. Because fire has both benefits and drawbacks, the optimum amount and timing of prescribed fire is an area of active research and better information on the initial chemistry and evolution of BB emissions is a major need (Haines and Cleaves, 1999; Sandberg et al., 2002; Yoder et al., 2003; Kauffman, 2004; Stephens et al., 2007; Akagi et al., 2011).

Next we summarize the limited amount of data available on the emissions and downwind chemical evolution of trace gases and particles from BB in the contiguous US. Groundbased measurements of prescribed fire emissions from various temperate fuel types in the US were carried out by Hardy and Teesdale (1991). Hardy et al. (1996) measured smoke emissions from chaparral fires in southern California (CA) and reported emission factors (EF, g compound emitted per $\mathrm{kg}$ dry biomass burned) for PM (total PM, $\mathrm{PM}_{2.5}, \mathrm{PM}_{10}$ ), $\mathrm{CO}, \mathrm{CO}_{2}, \mathrm{CH}_{4}$, and non-methane hydrocarbons by combustion process (i.e. flaming or smoldering). Prescribed fire emissions have also been measured from airborne platforms (Cofer III. et al., 1988; Radke et al., 1990; Yokelson et al., 1999). Ward et al. (1993) compiled the first extensive inventory of particulate matter and trace gas EF for prescribed fires in the US, which estimated EF based on combustion efficiency from field and laboratory measurements for the different classes of biomass consumed. Numerous laboratory studies of the initial emissions from burning temperate ecosystem fuels have been conducted (e.g. Yokelson et al., 1996, 1997; Goode et al., 1999; McMeeking et al., 2009; Veres et al., 2010; Burling et al., 2010; Hosseini et al., 2010). The studies discussed above focused on measuring fresh smoke emissions, which can help properly initialize models that predict the evolution of BB smoke as it ages downwind. However, they did not directly observe post-emission photochemical and heterogeneous processes. Recently, several laboratory studies investigated the post emission processing of smoke from temperate fuels (Grieshop et al., 2009; Heringa et al., 2011; Hennigan et al., 2011; Cubison et al., 2011), but the aging of smoke from real fires is difficult to reproduce in a laboratory. The behavior and fate of these emissions are important, as air pollutants from fires can remain in the atmosphere for many days and they can also be transported thousands of kilometers (Lee et al., 2005; Yokelson et al., 2007a; Warneke et al., 2009). The $\mathrm{PM}_{2.5}$ emissions interact with trace gases via heterogeneous chemistry and gas-particle interconversion processes as smoke plumes age (Mühle et al., 2007; Phuleria et al., 2005). The gas-particle interactions can increase or decrease the amount of $\mathrm{PM}_{2.5}$ and also change the aerosol mixing state and lifetime (Petters et al., 2009). Some trace gases in BB smoke are rapidly depleted post-emission via reaction with the hydroxyl radical $(\mathrm{OH})$, while others (e.g. $\mathrm{O}_{3}$, $\mathrm{HCHO}$ ) are created from oxidation of non-methane organic compounds (NMOC). Most previous field studies of smoke aging focused on major biomass burning regions such as the tropics (Reid et al., 1998; Hobbs et al., 2003; Yokelson et al., 2009), where $\sim 70-80 \%$ of biomass burning is thought to occur (Crutzen and Andreae, 1990; van der Werf et al., 2010). The only field study that tracked the evolution of an isolated aging plume from a fire in temperate fuels that we know of followed the evolution of the plume from the Quinalt prescribed fire in the US Pacific Northwest for only $30 \mathrm{~min}$ (Trentmann et al., 2003). Thus, more field measurements of plume evolution in temperate ecosystems are needed to improve our understanding of the trade-offs between air quality and ecosystem health and between wild and prescribed fires (Sandberg et al., 2002).

Two plume evolution processes are especially important, both domestically and globally, but are poorly understood: (1) secondary organic aerosol (SOA) formation, and (2) $\mathrm{O}_{3}$ formation. The atmospheric influence of pollution sources is studied by modeling the dispersion and chemical evolution 
of the emissions with local to global scale models (e.g. Alvarado and Prinn, 2009; Byun and Schere, 2006; Heald et al., 2005). Recently, numerous studies in urban plumes have observed rapid production of SOA in amounts up to ten times the original emissions of primary organic aerosol (POA), which greatly exceeds the predictions of standard aerosol modules in atmospheric chemistry models (de Gouw and Jimenez, 2009). This has spurred the development of new, largely empirical modeling approaches that can cope with the large increases (Robinson et al., 2007). In contrast, measurements of organic aerosol (OA) evolution in biomass burning smoke are rare and have thus far shown smaller and variable SOA formation compared to urban plumes. In an airborne study of a BB plume in Mexico (Yokelson et al., 2009) and a laboratory study of wood smoke (Grieshop et al., 2009) the OA/POA ratio increased to greater than two in about 1 and $3 \mathrm{~h}$, respectively. Capes et al. (2009) did not observe evidence of SOA formation in African BB emissions on the time scale of several days. Cubison et al. (2011) observed modest SOA formation that averaged about $25 \%$ of POA in boreal BB smoke. The laboratory study of Hennigan et al. (2011) observed OA/POA between 0.7 and 2.9 in BB smoke aged for 3-4.5 h, while Heringa et al. (2011) found that OA/POA rose to $4.1 \pm 1.4$ after $5 \mathrm{~h}$ for wood smoke aged in a smog chamber. We also note that biomass burning is known to emit species that are precursors for aqueous phase SOA such as glycolaldehyde and phenol (Yokelson et al., 1997; Perri et al., 2009; Lim et al., 2010) and that a large fraction of the organic gases emitted by BB are still unidentified (Karl et al., 2007; Warneke et al., 2011) and may play a role in several types of SOA formation. Many more measurements of $\mathrm{OA}$ evolution in $\mathrm{BB}$ plumes are needed to determine the relative importance of the different $\mathrm{OA} / \mathrm{POA}$ outcomes at various time scales and to understand the factors driving the variability.

A second major issue is understanding $\mathrm{O}_{3}$ production in biomass burning plumes. $\mathrm{O}_{3}$ production is evidently the norm in tropical BB plumes, but both production and destruction of $\mathrm{O}_{3}$ occurs in boreal $\mathrm{BB}$ plumes and little is known about $\mathrm{O}_{3}$ chemistry in temperate BB plumes (Akagi et al., 2011). The few available time-resolved observations of $\mathrm{O}_{3}$ formation in isolated plumes have proven difficult to reproduce even in specialized photochemical models (Trentmann et al., 2005; Alvarado and Prinn, 2009). Additional measurements of the $\mathrm{O}_{3}$ formation rate in various plume environments are needed to further develop the specialized models and ultimately guide the implementation of reasonably accurate $\mathrm{O}_{3}$ formation mechanisms into air quality models currently in wide use, such as CMAQ (Byun and Schere, 2006).

Here we report new field measurements that address the issues discussed above. We acquired the measurements during the San Luis Obispo Biomass Burning (SLOBB) experiment, which was carried out in November 2009 primarily in midcoast California. The main goal of SLOBB was to study the emissions and the evolution of gases and particles produced by prescribed burns on US Department of Defense lands. We measured many new emission factors for US prescribed fires during SLOBB and related field studies as detailed by Burling et al. (2011). In addition, a prescribed fire near Buellton, CA named the Williams Fire proved particularly opportune for the study of gas-phase photochemistry and particle transformations in a smoke plume. These processes are difficult to simulate in a laboratory and frequently inaccessible even for airborne platforms. The Williams Fire produced a long, clearly-identifiable, isolated plume above the boundary layer where the smoke evolved without influence from factors such as clouds, mixing with plumes from other pollution sources, or complex meteorology. Thus, the measurements provide an ideal case study to test the chemical mechanism of a smoke model. To our knowledge the Williams Fire is the first temperate zone fire for which the evolution of numerous trace gases and aerosol species in the plume was continuously tracked for smoke ages of more than one-half hour. Extensive particle and trace gas measurements in fresh and aged smoke (for ages up to $4.5 \mathrm{~h}$ old) were performed to quantify the changes in NMOC, $\mathrm{O}_{3}, \mathrm{NO}_{\mathrm{x}}, \mathrm{PAN}, \mathrm{NH}_{3}$, light scattering, inorganic and organic aerosol, refractory black carbon $(\mathrm{rBC})$, and the $\mathrm{rBC}$ mixing state. We describe and discuss these measurements in detail in the following sections.

\section{Experimental details}

\subsection{Instrument details}

\subsubsection{Airborne Fourier transform infrared spectrometer (AFTIR)}

The University of Montana AFTIR system and the instruments described below were deployed on a US Forest Service (USFS) Twin Otter. The AFTIR was used to measure 21 gas-phase species: water vapor $\left(\mathrm{H}_{2} \mathrm{O}\right)$, carbon dioxide $\left(\mathrm{CO}_{2}\right)$, carbon monoxide $(\mathrm{CO})$, methane $\left(\mathrm{CH}_{4}\right)$, nitric oxide (NO), nitrogen dioxide $\left(\mathrm{NO}_{2}\right)$, ammonia $\left(\mathrm{NH}_{3}\right)$, hydrogen cyanide ( $\mathrm{HCN})$, nitrous acid (HONO), peroxy acetyl nitrate (PAN), ozone $\left(\mathrm{O}_{3}\right)$, glycolaldehyde $\left(\mathrm{HCOCH}_{2} \mathrm{OH}\right)$, ethylene $\left(\mathrm{C}_{2} \mathrm{H}_{4}\right)$, acetylene $\left(\mathrm{C}_{2} \mathrm{H}_{2}\right)$, propylene $\left(\mathrm{C}_{3} \mathrm{H}_{6}\right)$, formaldehyde $(\mathrm{HCHO})$, methanol $\left(\mathrm{CH}_{3} \mathrm{OH}\right)$, furan $\left(\mathrm{C}_{4} \mathrm{H}_{4} \mathrm{O}\right)$, phenol $\left(\mathrm{C}_{6} \mathrm{H}_{5} \mathrm{OH}\right)$, acetic acid $\left(\mathrm{CH}_{3} \mathrm{COOH}\right)$, and formic acid $(\mathrm{HCOOH})$. Ram air was directed through a halocarbon-wax coated inlet and into a Pyrex multipass cell. The IR beam was directed into the cell where it traversed a total path length of $78 \mathrm{~m}$ and was then focused onto an MCT detector. The cell exchange time was about ten seconds when the flow control valves were open and IR spectra were collected at $1 \mathrm{~Hz}$. "Grab samples" of air were selected by closing the valves for 1-2 min to temporarily stop system flow to allow signal averaging on the smoke or background samples. The IR spectra were analyzed to identify and quantify all detectable compounds (Sect. 2.4.1). More details of the AFTIR system are 
given by Yokelson et al. (1999, 2003a). In this project, upgrades to the spectrometer electronics, transfer optics, and multipass cell led to a factor of three increase in sensitivity compared to the original system.

\subsubsection{Aerosol mass spectrometer (AMS)}

An Aerodyne compact time-of-flight (CToF) aerosol mass spectrometer (herein referred to as AMS) measured aerosol chemical composition in a repeating cycle for 4 out of every $12 \mathrm{~s}$ during flight, including within the smoke plume. An isokinetic particle inlet sampling fine particles with a diameter cut-off of a few microns (Yokelson et al., 2007b) supplied the AMS and a single particle soot photometer (SP2, Sect. 2.1.3). The AMS and SP2 do not measure super-micron particles, so the inlet transmission should not have affected our results. In addition, particles smaller than $1 \mu \mathrm{m}$ diameter account for nearly all the fine particle mass emitted by biomass fires (Radke et al., 1991; Reid et al., 2005b), so our composition analyses for fine particles should not be affected by the lack of sensitivity to super-micron particles. The AMS collected sub-micron particles via an aerodynamic lens into a high vacuum particle sizing chamber. At the end of the particle sizing chamber, the particles impact a $600{ }^{\circ} \mathrm{C}$ vaporizer and filament assembly where they are vaporized and ionized by electron impact. The resulting molecular fragments are then extracted into an ion time-of-flight chamber where they are detected and interpreted as mass spectra. The AMS has been described in great detail elsewhere (Drewnick et al., 2005; Canagaratna et al., 2007). A collection efficiency of 0.5 (Huffman et al., 2005; Drewnick et al., 2003; Allan et al., 2004) was applied to the AMS data, which were processed with the ToF-AMS Analysis Toolkit in Igor Pro 6 (Wavemetrics, Lake Oswego, OR) to retrieve the mass concentration at standard temperature and pressure $\left(\mu \mathrm{g} \mathrm{sm}^{-3}, 273 \mathrm{~K}, 1 \mathrm{~atm}\right)$ for the major non-refractory particle species: OA, non-sea salt chloride, nitrate, sulfate, and ammonium, with $<36 \%$ uncertainty. Adjustments to the default AMS unit mass resolution (UMR) fragmentation table were made for sulfate and nitrate concentrations. For instance, nitrate was corrected for organic interference at the nitrate peak at $\mathrm{m} / \mathrm{z} 30$ based on the results of Bae et al. (2007).

\subsubsection{Single particle soot photometer (SP2)}

Refractory black carbon ( $\mathrm{rBC}, \mu \mathrm{g} \mathrm{sm}{ }^{-3}$ ) was measured using a single particle soot photometer (SP2) (Stephens et al., 2003). The isokinetic particle inlet that supplied the AMS was followed by a three-way splitter and also supplied the SP2 with carefully matched flow rates. Particles were then drawn through a $1064 \mathrm{~nm} \mathrm{Nd:YAG} \mathrm{laser} \mathrm{cavity} \mathrm{where} \mathrm{light}$ scattered by the particles was measured by two avalanche photodiode detectors. Sufficiently light-absorbing particles (at $1064 \mathrm{~nm}$ ) were heated and eventually vaporized when passing through the beam. The emitted incandescent light was detected by two photomultiplier tubes with optical filters to measure light over two wavelength ranges. The incandescence signal was related linearly to the mass of $\mathrm{rBC}$, regardless of the presence or type of $\mathrm{rBC}$ coating (Moteki and Kondo, 2007). The sample flow into the SP2 was diluted with filtered air at a ratio of 7:1 for smoke plume samples near the source with high concentrations of particles. A dilution of $0.35: 1$ or no dilution was used for the less concentrated downwind samples. Information on the rBC mixing state was inferred from the time delay between the peak of the scattering and incandescence signals, which is a proxy for the time taken for coatings to evaporate before incandescence can occur (Schwarz et al., 2006). Particles with long time delays were considered "thickly coated", while those with shorter delays were "thinly coated" following Shiraiwa et al. (2007). The critical delay time needed for classification was based on the observed minimum in the bimodal frequency distribution of delay times for the rBC particles between 120 and $315 \mathrm{~nm}$ volume equivalent diameter and was $1.1 \mu$ s. The SP2 data products were collected at $>1 \mathrm{~Hz}$ and later averaged as needed to match the sampling rates of the other instruments.

\subsubsection{Other simultaneous measurements}

A $25 \mathrm{~mm}$ i.d. forward facing elbow "fastflow" inlet, colocated with the isokinetic and AFTIR inlets, fed air to a Radiance Research Model 903 nephelometer fit with a $2.5 \mu \mathrm{m}$ cut-off cyclone that measured the dry particle light scattering coefficient $\left(b_{\text {scat }}\right)$ at $530 \mathrm{~nm}$ at $0.5 \mathrm{~Hz}$. The $b_{\text {scat }}$ was converted to $b_{\text {scat }}$ at STP and then to a mass of $\mathrm{PM}_{2.5}$ $\left(\mu \mathrm{g} \mathrm{sm}^{-3}\right)$ using a conversion factor (for fresh smoke) of $208800 \mu \mathrm{g} \mathrm{sm}^{-2}$ (equivalent to a mass scattering efficiency of $\sim 4.8 \mathrm{sm}^{2} \mathrm{~g}^{-1}$ ) obtained by a gravimetric calibration of the type described by Trent et al. (2000). The nephelometer inlet also supplied air to a non-dispersive infrared instrument (NDIR, LiCor model 6262), which measured $\mathrm{CO}_{2}$ at the same time as $b_{\text {scat }}$. Since the AFTIR also measured $\mathrm{CO}_{2}$, this allowed the $\mathrm{PM}_{2.5}$ measurements to be normalized to the trace gas data as described in detail below. A second NDIR (LiCor model 7000) measured $\mathrm{CO}_{2}$ (at $0.5 \mathrm{~Hz}$ ) from the third channel on the isokinetic particle inlet that also supplied the AMS and SP2 allowing the data from the latter instruments to be coupled to the trace gas data. Measurements of the ambient three-dimensional wind velocity, temperature, relative humidity, and barometric pressure at $1-\mathrm{Hz}$ were obtained with a wing-mounted Aircraft Integrated Meteorological Measuring System probe (AIMMS-20, Aventech Research, Inc.). Details of the AIMMS-20 probe and a performance evaluation are provided by Beswick et al. (2008). A chemiluminescence instrument measured ozone at $0.5 \mathrm{~Hz}$. 

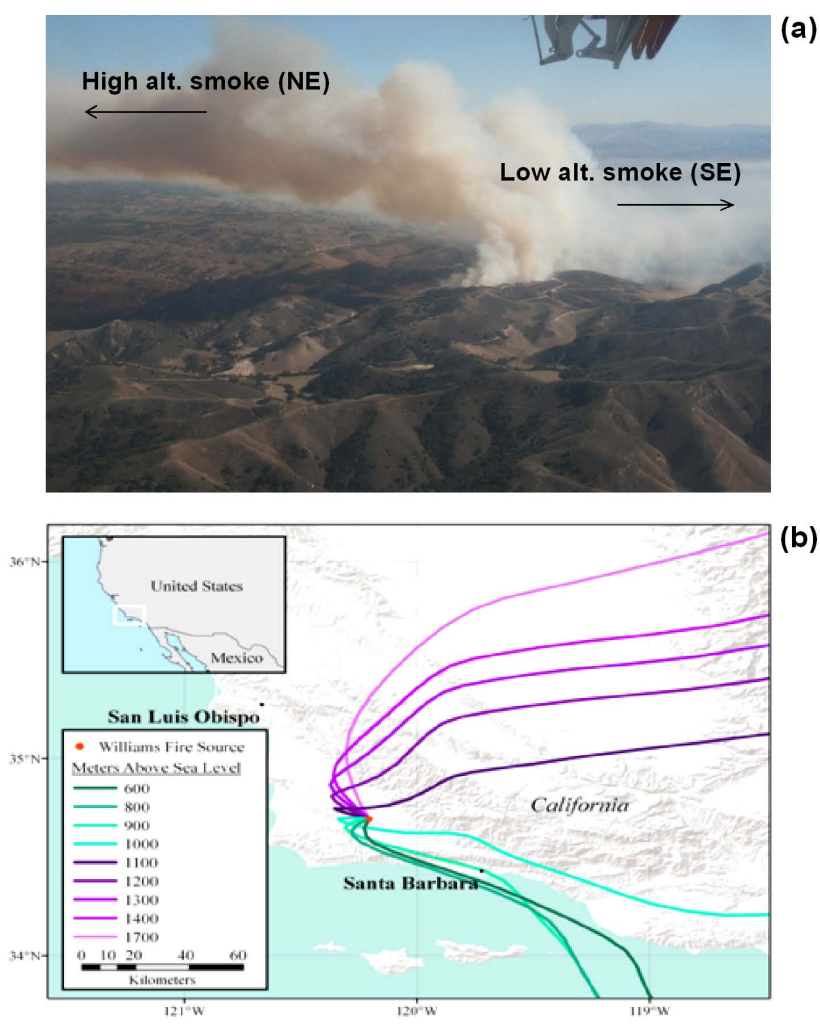

(a)

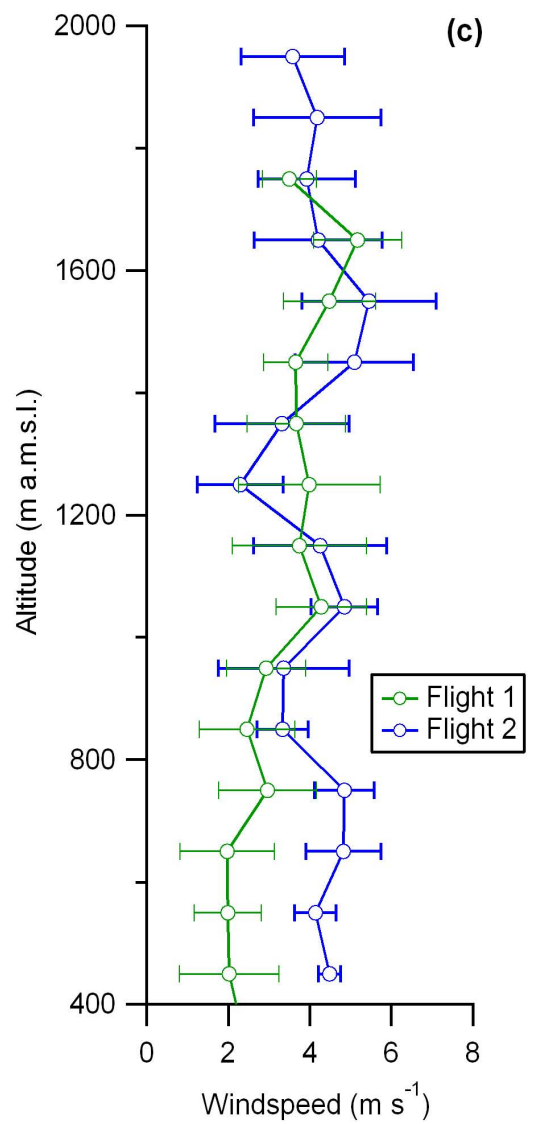

Fig. 1. (a) Photograph of the high- and low-altitude smoke plumes from the Williams Fire taken at 12:20 LT on 17 November 2009 from the USFS Twin Otter. (b) HYSPLIT forward trajectories starting at 11:00 LT at the Williams Fire (Draxler and Rolph, 2010; Rolph, 2010). Eight $24 \mathrm{~h}$ trajectories show air at 600-1000 m a.m.s.l. (green) drifting SE and air at 1100-1700 m a.m.s.l. (purple) drifting NE. (c) Vertical profile of windspeeds from Flights 1 (green) and 2 (blue).

\subsection{Vegetation and fire development}

The Williams prescribed fire was carried out on 17 November 2009 . The 81 hectare site $(\sim 10 \mathrm{~km}$ north of Buellton, California; $34^{\circ} 41^{\prime} 45^{\prime \prime} \mathrm{N}, 120^{\circ} 12^{\prime} 23^{\prime \prime} \mathrm{W}$ ) covered several hillsides with various aspects. The land cover can be classified as chaparral and the vegetation burned consisted of scrub oak woodland understory and coastal sage scrub, which is a mixture of California sagebrush (Artemisia californica) with coyote brush (Baccharis pilularis), black sage (Salvia mellifera), and California buckwheat (Eriogonum fasciculatum). Dead fuel moisture ranged from 9 to $15 \%$ with higher moisture in the larger diameter fuels. Live fuel moisture was $70 \%$, which is below average compared to normally observed values. Ground level winds were light and variable at $2-8 \mathrm{~km} \mathrm{~h}^{-1}$. Ground level relative humidity (RH) ranged from 26-11\% between 09:00-13:00 LT (PST, UTC8). Surface temperature ranged from $19^{\circ} \mathrm{C}$ at 09:00 LT to $24^{\circ} \mathrm{C}$ at 12:20 LT. Skies were clear all day. (Fuels and surface weather information, J. McCarty, personal communication, Santa Barbara County Fire Department, 2009.) Igni- tion of the Williams Fire began at approximately 09:57 LT. The plume built up gradually and most of the smoke rose to $\sim 1200-1336 \mathrm{~m}$ above mean sea level (ma.m.s.l.) and then drifted northeast. Some smoke detrained at lower altitudes (below $\sim 600 \mathrm{~m}$ a.m.s.l.) and drifted southeast, settling into nearby valleys (Fig. 1a). Our visual observations were consistent with air parcel forward trajectory simulations using HYSPLIT (NOAA Air Resources Laboratory, http://ready.arl.noaa.gov/HYSPLIT.php), which shows low-altitude trajectories $(600-1000$ m a.m.s.l., Fig. 1b) originating at the source traveling southeast, while higher altitude trajectories (1100-1700 ma.m.s.l.) traveled northeast (Fig. 1b). The upwind vertical profiles of temperature and water vapor mixing ratio from the AIMMS-20 (Supplement Fig. S1) showed that the top of the boundary layer was located at $\sim 800 \mathrm{~m}$ a.m.s.l. ( $\sim 450 \mathrm{~m}$ above ground level, or a.g.l.) and the AIMMS-20 wind direction data confirmed the shift in wind direction modeled by HYSPLIT at $1100 \pm 100 \mathrm{~m}$ a.m.s.l. The bulk of the smoke was sufficiently buoyant to penetrate the temperature inversion and rose to $\sim 1200 \mathrm{~m}$ a.m.s.l. where it encountered an average 


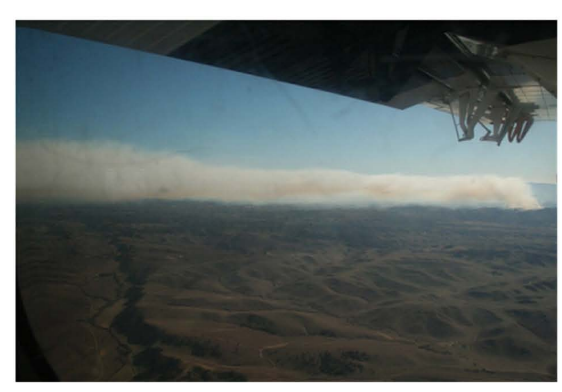

(a)

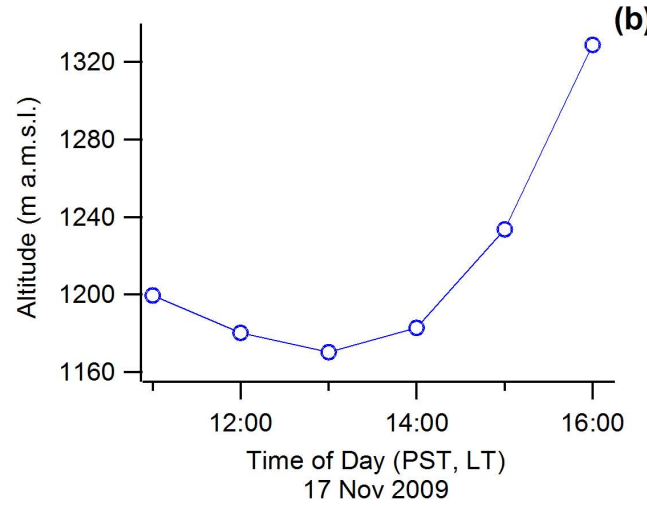

Fig. 2. (a) Side view of the Williams Fire high altitude plume at 12:40 LT from $\sim 58 \mathrm{~km}$ downwind. (b) HYSPLIT trajectory for source air starting at 11:00 LT and $1200 \mathrm{~m}$ a.m.s.l. No significant altitude gain is modeled in the first $\sim 4 \mathrm{~h}$ since emission.

windspeed of $\sim 5 \mathrm{~m} \mathrm{~s}^{-1}$ (Fig. 1c). Low-altitude smoke dispersed slowly $\left(\sim 2.5 \mathrm{~m} \mathrm{~s}^{-1}\right.$ was the average windspeed at altitudes $<1200 \mathrm{~m}$ a.m.s.l. during Flights 1 and 2) and tended to collect in low-lying areas as discussed further in Sect. 3.5.

The high altitude plume that drifted northeast from the source was isolated from other pollution sources and unimpeded by topography as seen in the photograph taken from $\sim 58 \mathrm{~km}$ downwind (Fig. 2a). The high altitude plume gradually rose from $\sim 1200 \mathrm{~m}$ a.m.s.l. at the source to $\sim 1800 \mathrm{~m}$ a.m.s.l. at $\sim 58 \mathrm{~km}(4.5 \mathrm{~h})$ downwind, but HYSPLIT trajectories starting at $1200 \mathrm{~m}$ a.m.s.l. failed to capture this observed behavior, showing no substantial altitude gain/loss for at least $4 \mathrm{~h}$ following fire ignition (Fig. 2b). The observed rise might have been due to self lofting since the high levels of $\mathrm{O}_{3}$ and black carbon in the plume would readily absorb significant amounts of solar energy. By 14:30 LT the fire had transitioned to mainly smoldering combustion with minimal plume rise.

\subsection{Flight details}

Two flights (mid-morning and afternoon) were conducted onboard the Twin Otter aircraft to sample initial emissions and aged smoke. Table 1 summarizes the times, locations, and meteorological conditions for AFTIR samples taken during both flights. For every plume sample on both flights we also collected a background sample at similar altitude just outside the plume.

Flight 1 occurred from 10:29-13:10 LT. We arrived at the site of the fire approximately $30 \mathrm{~min}$ after initial ignition, at which time the fire was beginning to produce a large plume of thick, white and brown smoke. From 10:50-12:19LT we collected ten samples of "nascent" smoke (smoke "just created" or "emerging from another form") (Samples 1-6, 8, $10-12$ in Table 1). The source samples were collected $\sim 600$ $1300 \mathrm{~m}$ a.m.s.l. at the center and top portions of the single updraft core. After 12:30 LT we concentrated on sampling the smoke downwind at $\sim 1200 \mathrm{~m}$ a.m.s.l., making perpendicular plume transects in an "S" shaped pattern and sampling the smoke eight times $4.5-16.1 \mathrm{~km}$ from the source (see flight path and AFTIR smoke sample locations in Fig. 3).

Flight 2 was conducted from 14:20-15:47 LT and sampled the high altitude plume at $1200-1900 \mathrm{~m}$ a.m.s.l. and $27-58 \mathrm{~km}$ from the source. From 14:45-15:16 LT we collected 10 grab samples of aged smoke $2.4-4.5 \mathrm{~h}$ old. We obtained estimated emission times by first calculating the average windspeed for incremental altitude bins of $100 \mathrm{~m}$ a.m.s.l. The smoke sample distance from the plume source was then divided by the average windspeed at the sample altitude. Estimated times since emission, or smoke "ages", were calculated for all the downwind samples from both flights (Table 1) using this methodology. This method implies that the oldest smoke sample had aged approximately $4.5 \mathrm{~h}$. In addition, based on the estimated emission time of each downwind sample: 14 of the 18 downwind samples from the two flights were likely emitted during the time we were sampling the source (10:50-12:19LT) and the other 4 downwind samples were emitted within 20 min of our source sampling period, supporting that the data are pseudo-Lagrangian. The Williams Fire plume was visible in GOES images and the position of the plume in the last daytime image $(\sim 16: 45 \mathrm{LT}$, acquired after Flight 2) is indicated in yellow in Fig. 3. Our measurements covered $\sim 70 \%$ of the distance the plume traveled the first day.

\subsection{Data processing and synthesis}

\subsubsection{FTIR spectral analysis}

We use nonlinear least squares, multi-component fits to regions of the IR spectra with the HITRAN spectral database (Rothman et al., 2009) and reference spectra from the Pacific Northwest National Laboratory (Sharpe et al., 2004; Johnson et al., 2006, 2010) to obtain mixing ratios in both the smoke and background spectra for most compounds (Griffith, 1996; Burling et al., 2010). For these compounds the 
Table 1. Smoke samples from the Williams Fire obtained during Flights 1 and 2.

\begin{tabular}{|c|c|c|c|c|c|c|c|c|c|c|}
\hline Sample & $\begin{array}{l}\text { Time } \\
\text { (LT) }\end{array}$ & $\begin{array}{l}\text { Latitude } \\
\left({ }^{\circ} \mathrm{N}\right)\end{array}$ & $\begin{array}{l}\text { Longitude } \\
\left({ }^{\circ} \mathrm{W}\right)\end{array}$ & $\begin{array}{r}\text { Altitude } \\
\text { (m a.m.s.l.) }\end{array}$ & $\begin{array}{c}\text { Pressure } \\
(\mathrm{hPa})\end{array}$ & $\begin{array}{c}\text { Relative } \\
\text { Humidity } \\
\text { (RH\%) }\end{array}$ & $\begin{array}{c}\text { Outside Air } \\
\text { Temperature } \\
\left({ }^{\circ} \mathrm{C}\right)\end{array}$ & $\begin{array}{c}\text { Distance } \\
\text { From Fire } \\
\text { Source }(\mathrm{km})\end{array}$ & $\begin{array}{l}\text { Time Since } \\
\text { Emission } \\
\text { (h:min:s) }\end{array}$ & $\begin{array}{c}\text { Estimated } \\
\text { Emission } \\
\text { Time (LT) }\end{array}$ \\
\hline \multicolumn{11}{|l|}{ Flight 1} \\
\hline 1 & $10: 51: 13$ & $34^{\circ} 41^{\prime} 40^{\prime \prime}$ & $120^{\circ} 12^{\prime} 13^{\prime \prime}$ & 817 & 923.0 & 13.0 & 16.6 & 0.31 & 0:02:04 & 10:49:09 \\
\hline 2 & $10: 55: 45$ & $34^{\circ} 41^{\prime} 41^{\prime \prime}$ & $120^{\circ} 12^{\prime} 18^{\prime \prime}$ & 819 & 919.2 & 14.0 & 17.3 & 0.21 & $0: 01: 25$ & $10: 54: 20$ \\
\hline 3 & 11:02:01 & $34^{\circ} 41^{\prime} 42^{\prime \prime}$ & $120^{\circ} 12^{\prime} 18^{\prime \prime}$ & 871 & 918.0 & 12.4 & 17.3 & 0.16 & 0:01:05 & $11: 00: 56$ \\
\hline 6 & $11: 20: 47$ & $34^{\circ} 42^{\prime} 4^{\prime \prime}$ & $120^{\circ} 12^{\prime} 11^{\prime \prime}$ & 1336 & 865.3 & 11.2 & 15.4 & 0.65 & 0:03:05 & $11: 17: 42$ \\
\hline 7 & $11: 31: 55$ & $34^{\circ} 46^{\prime} 35^{\prime \prime}$ & $120^{\circ} 10^{\prime} 59^{\prime \prime}$ & 1230 & 877.6 & 15.5 & 15.3 & 9.21 & $0: 37: 27$ & $10: 54: 28$ \\
\hline 8 & $11: 55: 25$ & $34^{\circ} 42^{\prime} 39^{\prime \prime}$ & $120^{\circ} 12^{\prime} 41^{\prime \prime}$ & 1196 & 882.3 & 13.4 & 15.2 & 1.71 & $0: 07: 35$ & $11: 47: 50$ \\
\hline 9 & 11:59:58 & $34^{\circ} 43^{\prime} 42^{\prime \prime}$ & $120^{\circ} 10^{\prime} 35^{\prime \prime}$ & 1192 & 881.8 & 16.8 & 15.3 & 4.55 & 0:20:08 & $11: 39: 50$ \\
\hline 10 & 12:08:08 & $34^{\circ} 41^{\prime} 44^{\prime \prime}$ & $120^{\circ} 12^{\prime} 30^{\prime \prime}$ & 621 & 938.7 & 26.3 & 17.8 & 0.18 & $0: 01: 23$ & $12: 06: 45$ \\
\hline 11 & $12: 15: 24$ & $34^{\circ} 41^{\prime} 45^{\prime \prime}$ & $120^{\circ} 12^{\prime} 23^{\prime \prime}$ & 624 & 936.3 & 25.9 & 18.3 & 0.00 & 0:00:00 & $12: 15: 24$ \\
\hline 16 & $12: 44: 57$ & $34^{\circ} 52^{\prime} 18^{\prime \prime}$ & $120^{\circ} 10^{\prime} 44^{\prime \prime}$ & 1196 & 879.9 & 14.4 & 15.6 & 19.7 & $1: 27: 21$ & $11: 17: 36$ \\
\hline 17 & $12: 47: 56$ & $34^{\circ} 50^{\prime} 50^{\prime \prime}$ & $120^{\circ} 6^{\prime} 26^{\prime \prime}$ & 1210 & 884.0 & 12.5 & 15.8 & 19.1 & $1: 17: 44$ & $11: 30: 12$ \\
\hline 18 & $12: 55: 27$ & $34^{\circ} 48^{\prime} 21^{\prime \prime}$ & $120^{\circ} 10^{\prime} 57^{\prime \prime}$ & 1163 & 888.6 & 16.3 & 15.9 & 12.4 & $0: 55: 03$ & $12: 00: 24$ \\
\hline \multicolumn{11}{|l|}{ Flight 2} \\
\hline 19 & $14: 45: 06$ & $34^{\circ} 55^{\prime} 28^{\prime \prime}$ & $120^{\circ} 6^{\prime} 15^{\prime \prime}$ & 1259 & 879.9 & 14.7 & 15.4 & 27.1 & $3: 17: 12$ & $11: 27: 54$ \\
\hline 20 & 14:49:08 & $35^{\circ} 4^{\prime} 34^{\prime \prime}$ & $120^{\circ} 6^{\prime} 40^{\prime \prime}$ & 1744 & 825.8 & 12.4 & 14.0 & 43.2 & $3: 03: 30$ & $11: 45: 38$ \\
\hline 21 & $14: 50: 06$ & $35^{\circ} 6^{\prime} 31^{\prime \prime}$ & $120^{\circ} 7^{\prime} 33^{\prime \prime}$ & 1790 & 821.2 & 15.3 & 12.7 & 46.5 & $3: 17: 35$ & $11: 32: 31$ \\
\hline 22 & $14: 52: 41$ & $35^{\circ} 8^{\prime} 16^{\prime \prime}$ & $120^{\circ} 5^{\prime} 52^{\prime \prime}$ & 1898 & 810.1 & 13.7 & 12.9 & 50.2 & $3: 20: 17$ & $11: 32: 24$ \\
\hline 23 & $14: 56: 11$ & $35^{\circ} 9^{\prime} 40^{\prime \prime}$ & $120^{\circ} 2^{\prime} 56^{\prime \prime}$ & 1899 & 813.2 & 13.5 & 12.7 & 53.7 & $3: 34: 29$ & $11: 21: 42$ \\
\hline 24 & $14: 56: 48$ & $35^{\circ} 10^{\prime} 52^{\prime \prime}$ & $120^{\circ} 3^{\prime} 42^{\prime \prime}$ & 1882 & 813.3 & 14.3 & 12.2 & 55.6 & $3: 41: 56$ & $11: 14: 52$ \\
\hline 25 & $14: 59: 48$ & $35^{\circ} 11^{\prime} 56^{\prime \prime}$ & $120^{\circ} 2^{\prime} 37^{\prime \prime}$ & 1979 & 801.2 & 13.1 & 12.3 & 57.9 & $4: 29: 44$ & 10:30:04 \\
\hline
\end{tabular}

excess mixing ratio for any species " $X$ " (denoted $\Delta X)$ is the mixing ratio of species " $X$ " in the plume sample minus its mixing ratio in the background air. For $\mathrm{HCN}, \mathrm{NO}$, and $\mathrm{NO}_{2}$ we determine the excess mixing ratios directly from absorbance spectra via spectral subtraction or peak integration (Yokelson et al., 1997). The absorbance spectra are made using background spectra acquired at nearly the same pressure. The NO detection limit is $\sim 25 \mathrm{ppb}$ and all excess mixing ratios below this concentration were omitted. The detection limit for the other compounds reported here is $1-10 \mathrm{ppb}$.

\subsubsection{Estimation of excess mixing ratios, normalized ex- cess mixing ratios (NEMR), emission ratios (ER), and emission factors (EF)}

The procedure to calculate excess mixing ratios for the AFTIR data is given above. Excess mixing ratios can also be calculated from the continuous data (SP2, $\mathrm{CO}_{2}, b_{\text {scat }}$ ) and repetitive discrete samples (AMS). In both these cases, we compute the background value from the average of a large number of points at the plume altitude (but outside the plume) and then subtract that background from the values obtained in the plume.

The normalized excess mixing ratio (NEMR) is obtained by dividing $\Delta X$ by the excess mixing ratio of another species $(\Delta Y)$ measured at the same time and location; usually a fairly long-lived plume "tracer" such as $\Delta \mathrm{CO}$ or $\Delta \mathrm{CO}_{2}$. For the Williams Fire, the NEMRs for all species (except $\Delta \mathrm{NH}_{3}$ referenced to $\Delta \mathrm{CO}$ or $\Delta \mathrm{CO}_{2}$ ) measured at the source of the fire did not vary greatly as the fire progressed through the available fuels. We incorporated the ten measurements of the source NEMR into an estimate of the fire-average initial molar emission ratio (ER) as described below. The ER has two important uses: (1) Since the $\mathrm{CO}$ or $\mathrm{CO}_{2}$ tracers dilute at the same rate as the other species, differences between the ERs and the NEMRs measured downwind allow us to quantify post-emission gas-phase chemistry and gas-particle 


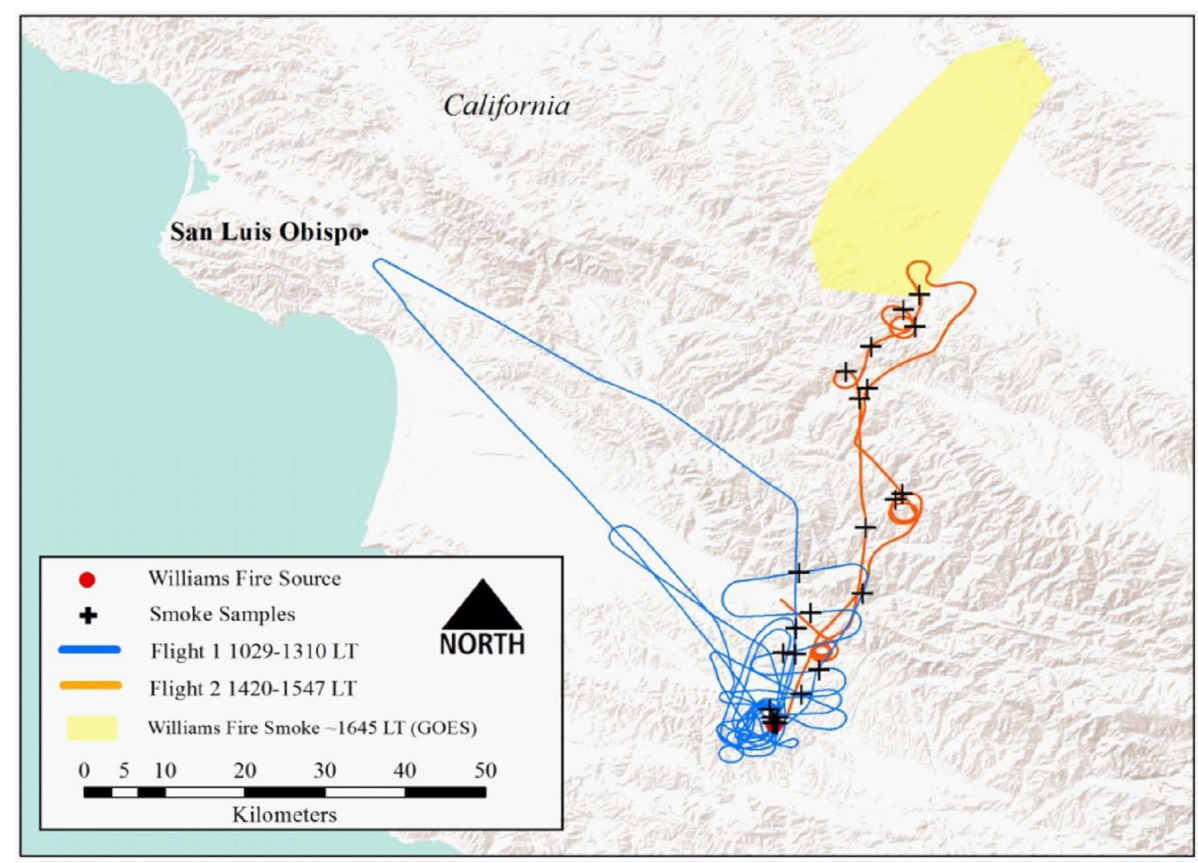

Fig. 3. The flight paths and the location of smoke samples for Flight 1 (blue) and Flight 2 (orange). The approximate position of the densest smoke in the Williams Fire plume (yellow) during the last daytime GOES image ( 16:45 LT) captured after our second flight on 17 November 2009. The overlay shows that our measurements probed most of the daytime plume evolution that occurred on 17 November (plume image from http://www.firedetect.noaa.gov).

partitioning; and (2) The ER can be used to calculate emission factors (EF) as described below.

The measurement of a NEMR is most accurate when both species were measured simultaneously on the same instrument (e.g. two gases in the AFTIR cell or two particle species on the AMS). When comparing NEMR that were determined using data from two different instruments, error can be introduced due to the different time responses of the instruments. However, this error can be largely eliminated for continuous instruments by deriving the NEMR from a comparison of the integrals over the whole plume sample. In addition, in the dispersed, downwind plume, the excess mixing ratios tended to vary slowly in time and space compared to measurement frequency. In this work, we most often use NEMR relative to $\triangle \mathrm{CO}$ since $\mathrm{CO}$ has a lifetime of several months at $\sim 35^{\circ} \mathrm{N}$ in November, low background variability, and there were no other major sources of $\mathrm{CO}$ noted in the vicinity. In some cases we show downwind NEMR to $\mathrm{CO}_{2}$ since that was the relevant co-measured species.

We computed fire-average initial emission ratios as our best estimate of the starting conditions in the plume using our ten source samples as follows. For grab samples we take the fire-average ER as the slope of the linear least-squares line with the intercept forced to zero when plotting $\Delta X$ against $\Delta Y$ (Yokelson et al., 1999). For example, the slope of the plot of $\Delta X$ vs. $\Delta C O$ yields the initial molar emission ratio for compound " $X$ " to $\mathrm{CO}$ and the uncertainty is the $1 \sigma$ standard error in the slope (Fig. 4a, b). The intercept is forced to zero since the background concentration is typically well known and variability in the plume can affect the intercept if it is not forced. This method heavily weights the large values that may reflect more intense combustion and were collected with higher signal-to-noise. Smoke samples collected more than $1.8 \mathrm{~km}$ from the source showed signs of aging $\left(\mathrm{O}_{3}\right.$ formation) and were not used to derive the initial ER. We obtained initial mass emission ratios for the AMS species, $\mathrm{rBC}$, and $\mathrm{PM}_{2.5}$ to $\mathrm{CO}_{2}$ since $\mathrm{CO}_{2}$ was measured on the same inlet. These ratios were computed by comparing the integrated excess amounts as the aircraft passed through the nascent smoke as mentioned above. For the set of passes through the fresh smoke we plot the integrals of the excess values from the AMS and continuous instruments versus the integrals of excess $\mathrm{CO}_{2}$ and obtain the ER from the slope, analogous to the grab sample plots (Fig. 4c, d). To test the robustness of our integral-based AMS ERs to $\mathrm{CO}_{2}$, we compared them to ER obtained by plotting the excess values from the $4 \mathrm{~s}$ discrete samples versus the values of $\Delta \mathrm{CO}_{2}$ measured during the same $4 \mathrm{~s}$ interval. In nearly all cases we obtained agreement within $5 \%$, except for sulfate, which was reconstructed based on samples of smoke with low levels of organic loading where the AMS fragmentation table gave reasonable results. The major sulfate fragments in the AMS spectrum are $\mathrm{m} / \mathrm{z}, 48$ (has minor organic interference based on unpublished high resolution data of a similar fuel type), $m / z 64, m / z 80$, $\mathrm{m} / \mathrm{z}, 81$ and $\mathrm{m} / \mathrm{z}$ 98. The ratios of $\mathrm{m} / \mathrm{z}, 64, \mathrm{~m} / \mathrm{z}, 80, \mathrm{~m} / \mathrm{z}, 81$ and $m / z, 98$ to $\mathrm{m} / \mathrm{z} 48$ were calculated for low smoke levels 

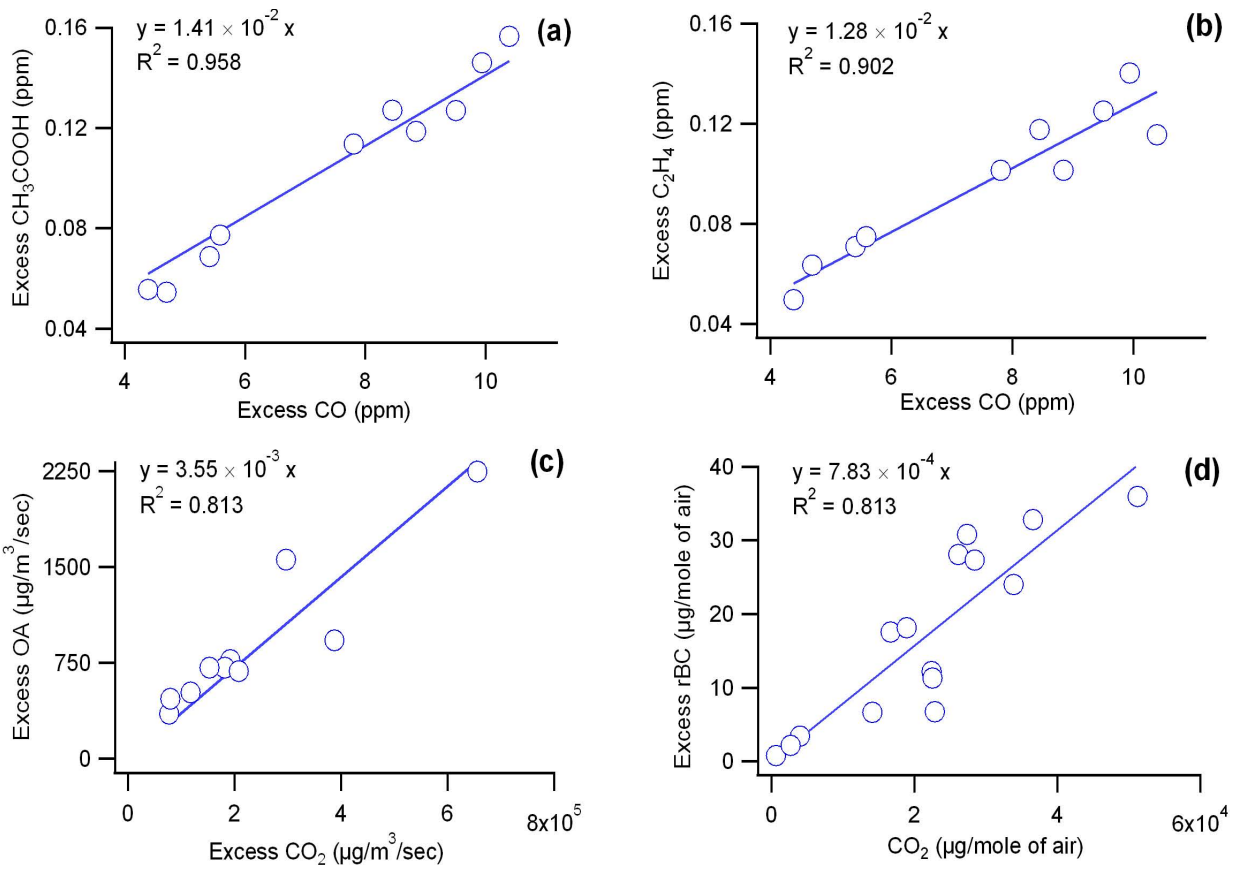

Fig. 4. Emission ratio plots for (a) $\Delta \mathrm{CH}_{3} \mathrm{COOH} / \Delta \mathrm{CO}$ and (b) $\Delta \mathrm{C}_{2} \mathrm{H}_{4} / \Delta \mathrm{CO}$ measured by AFTIR. (c) $\Delta \mathrm{OA} / \Delta \mathrm{CO} 2 \mathrm{measured} \mathrm{by} \mathrm{AMS} \mathrm{and}$ NDIR. (d) $\Delta \mathrm{rBC} / \Delta \mathrm{CO}_{2}$ measured by SP2 and NDIR.

where organic interference at these masses is low, and were then applied to the higher loading smoke samples. The issues related to calculating inorganic aerosol concentrations from UMR AMS data during episodes of high organic loading is an active area of research and will be presented in future work.

For any carbonaceous fuel, the source ERs can be used to calculate emission factors (EF) expressed in grams of compound emitted per kilogram of biomass burned (on a dry weight basis) using the carbon mass-balance method (as explained in Yokelson et al., 1996, 1999). The carbon mass balance method is most accurate when the fraction of carbon in the fuel is precisely known and all the burnt carbon is volatilized and detected. Based on carbon content analysis of about 50 chaparral vegetation samples during a companion study (Burling et al., 2010) and literature values for similar fuels (Susott et al., 1996; Ebeling and Jenkins, 1985), we assumed a carbon content of $50 \%$ by mass on a dry weight basis for the fuels that burned in the Williams Fire. The actual fuel carbon percentage likely varied from this by less than a few percent. EF scale linearly with the assumed fuel carbon fraction. Total $\mathrm{C}$ in this study was determined from the sum of the $\mathrm{C}$ from AFTIR species, $\mathrm{rBC}$, and an organic carbon (OC) value based on the assumption that $\mathrm{OA} / \mathrm{OC}$ was 1.6 in fresh smoke (Yokelson et al., 2009). This sum could underestimate the total carbon by $1-2 \%$ due to unmeasured C. That would lead to a slight, across the board overestimate of our calculated EF by a factor of 1-2\% (Akagi et al., 2011).

\section{Results and discussion}

\subsection{Initial emissions compared to other chaparral fires}

The fire-average molar emission ratios for the Williams Fire (computed as described in Sect 2.4.2) are presented in Table 2. A detailed comparison of the Williams Fire initial emissions (ER and EF) to the emissions from other chaparral fires sampled during SLOBB and chaparral fires sampled in other studies is presented by Burling et al. (2011). Here we simply note that the Williams Fire had similar ERs, EFs, and modified combustion efficiency (MCE, 0.933) to those reported in the literature for other chaparral fires (Radke et al., 1991; Hardy et al., 1996; Burling et al., 2011). The one exception is that Radke et al. (1991) reported a study-average $\mathrm{EF}\left(\mathrm{PM}_{2.5}\right)\left(15.93 \pm 6.88 \mathrm{~g} \mathrm{~kg}^{-1}\right)$ that is significantly higher than our $\mathrm{EF}\left(\mathrm{PM}_{2.5}\right)$ or the literature average (Burling et al., 2011, $\left.\sim 8 \mathrm{~g} \mathrm{~kg}^{-1}\right)$, which likely reflects that they sampled more of the smoldering phase near the end of the fires, as smoldering normally produces higher EF(PM) (Ferek et al., 1998). Radke et al. (1991) note that their spot measurements of particle EF increased by as much as a factor of three as the fraction of smoldering combustion increased. Rather than measure samples of smoldering combustion as the fire died down, we focused first on characterizing the emissions that were produced by the bulk of the fuel consumed and then on the evolution of those emissions in the downwind plume. 


\subsection{Plume evolution}

Many chemical and physical changes can affect nascent smoke as it begins to mix with ambient air. These changes include photochemical transformations, mixing with biogenic and/or anthropogenic pollutants, cloud processing, coagulation, and gas-to-particle conversion (Reid et al., 1998). The complexity of the aging scenario can vary greatly, depending on factors such as temperature, dispersion altitude, time of day, humidity, cloud cover, the initial emissions, and the proximity of other emission sources. In this study, the Williams Fire produced an isolated, nearly "undisturbed" plume, which provides a rare, valuable opportunity to test the mechanism of a photochemical model. A companion paper will use our observations of the Williams Fire to test and evaluate an advanced smoke plume chemistry model (Alvarado and Prinn, 2009).

The evolution of the reactive species we could measure over the course of $4 \mathrm{~h}$ following emission is summarized in Table 2. To illustrate photochemical changes in the plume it is useful to have a best estimate of the starting NEMR and uncertainty to compare to downwind NEMR. We use the slope-based fire-average ER as our best estimate of the likely starting NEMR for primary species measured in any individual smoke parcel downwind. Sloped based initial NEMRs were also calculated for secondary species such as ozone and PAN (shown in Table 2) though the concept of an ER does not strictly apply to these species. We use the standard deviation in the mean of the ten source NEMRs as our best estimate of the uncertainty in the starting NEMR for all species with downwind data (also shown in Table 2). Stable species that did not change significantly for $4 \mathrm{~h}$ after emission and species that dropped below our detection limit in that time are also included in Table 2 just to provide a more complete reference. The uncertainty in the ER shown for these species is the standard error in the slope and no downwind data is shown except for rBC. Absolute uncertainties in the ERs and NEMRs have a component from random and systematic instrumental errors, sampling representativeness, and other issues; but many of these errors should not greatly impact the study of plume evolution. As an example we note that downwind smoke was only sampled in the high altitude plume and the low-altitude source samples could potentially represent smoke that instead detrained in the low elevation plume. However, the source ERs were not significantly dependent on altitude. In a few cases we will illustrate this by comparing the downwind NEMRs to an alternate ER based solely on the high altitude source samples and show that the impact of this was small.

At this point it should be clear that fires do not produce "ideal" plumes. Instead there is some temporal and spatial fluctuation about the average ER and smoke parcels mix with both background air and other parts of the plume, which explains some of the variation in the downwind NEMRs. We fit the evolution of the NEMRs to various "best fit" functions to

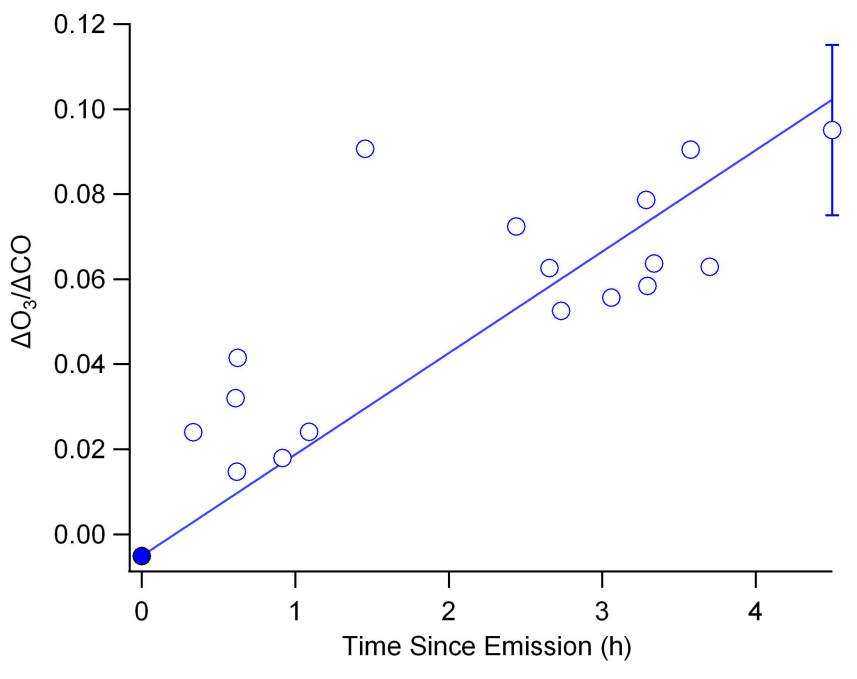

Fig. 5. $\Delta \mathrm{O}_{3} / \Delta \mathrm{CO}$ vs. time since emission (h). Individual source samples are not shown and we instead show the initial negative $\Delta \mathrm{O}_{3} / \Delta \mathrm{CO}$ NEMR (solid circle). The error bar reflecting the standard deviation in the mean of the ten source measurements is too small to be visible. The downwind error bar is an estimate of the uncertainty in the oldest individual downwind sample.

estimate the final NEMR at the age of the last measurement (4-4.5 $\mathrm{h}$ time since emission), to assist in discerning differences between the final downwind NEMR and the ER, and to estimate lifetimes. We report the final downwind NEMR and estimated uncertainty for the measured reactive species in Table 2. The uncertainty shown for the final NEMR is the uncertainty in individual downwind samples, but the uncertainty in whether a trend is occurring is smaller than shown by these uncertainties. We note that the functions used were selected empirically based on how well they fit the data and cannot necessarily be rigorously derived from the complex, sometimes unknown, underlying chemistry. Nor do we assume that these fits describe the behavior beyond the time since emission measured here. We show relative growth factors that compare the downwind and initial NEMRs (or ERs) over this time period to summarize the magnitude of species evolution that occurred in this photochemically active plume. Detailed discussions of these changes are presented in the remainder of this section.

\subsubsection{Ozone}

Ozone is an important secondary product formed in biomass burning smoke. Figure 5 shows the $\Delta \mathrm{O}_{3} / \Delta \mathrm{CO}$ NEMR tracked over the course of estimated times since emission of $0 \mathrm{~h}$ to $\sim 4.5 \mathrm{~h}$. The initial $\Delta \mathrm{O}_{3} / \Delta \mathrm{CO}$ NEMR (solid circle) is negative because the background air contained $\sim 50 \mathrm{ppb}$ of ozone that was quickly destroyed by fast reaction with $\mathrm{NO}$ emitted by the fire. Negative initial $\Delta \mathrm{O}_{3} / \Delta \mathrm{CO}$ NEMRs are common when sampling fresh smoke (Yokelson et al., 2003a). The y-intercept of a linear trendline was forced to the 
Table 2. Emission ratios (ER), initial and downwind NEMR for the Williams Fire.

\begin{tabular}{|c|c|c|c|c|c|c|}
\hline & $\begin{array}{l}\mathrm{ER}(\mathrm{mol} \mathrm{mol}-1) \\
\text { or initial NEMR }\end{array}$ & Uncertainty $^{\mathrm{a}}$ & $\begin{array}{c}\text { Downwind NEMR } \\
\text { (4-4.5 h since emission) }\end{array}$ & Uncertainty ${ }^{b}$ & $\begin{array}{l}\text { Factor Change } \\
\text { after } 4-4.5 \mathrm{~h}\end{array}$ & Uncertainty \\
\hline & Ratioed to $\Delta \mathrm{CO}_{2}$ & & & & & \\
\hline \multirow[t]{2}{*}{$\mathrm{CO}$} & $7.13 \times 10^{-2}$ & $5.50 \times 10^{-3}$ & & & & \\
\hline & Ratioed to $\Delta \mathrm{CO}$ & & & & & \\
\hline Methane $\left(\mathrm{CH}_{4}\right)$ & $8.72 \times 10^{-2}$ & $2.40 \times 10^{-3}$ & & & & \\
\hline Acetylene $\left(\mathrm{C}_{2} \mathrm{H}_{2}\right)$ & $2.72 \times 10^{-3}$ & $2.10 \times 10^{-4}$ & & & & \\
\hline Propylene $\left(\mathrm{C}_{3} \mathrm{H}_{6}\right)$ & $4.80 \times 10^{-3}$ & $8.00 \times 10^{-5}$ & & & & \\
\hline Phenol $\left(\mathrm{C}_{6} \mathrm{H}_{5} \mathrm{OH}\right)$ & $1.48 \times 10^{-3}$ & $1.70 \times 10^{-4}$ & & & & \\
\hline Furan $\left(\mathrm{C}_{4} \mathrm{H}_{4} \mathrm{O}\right)$ & $1.46 \times 10^{-3}$ & $8.00 \times 10^{-5}$ & & & & \\
\hline Methanol $\left(\mathrm{CH}_{3} \mathrm{OH}\right)$ & $1.67 \times 10^{-2}$ & $7.00 \times 10^{-4}$ & & & & \\
\hline Hydrogen Cyanide (HCN) & $1.30 \times 10^{-2}$ & $1.10 \times 10^{-3}$ & & & & \\
\hline Nitrous Acid (HONO) & $4.00 \times 10^{-3}$ & $6.10 \times 10^{-4}$ & & & & \\
\hline Ethylene $\left(\mathrm{C}_{2} \mathrm{H}_{4}\right)$ & $1.28 \times 10^{-2}$ & $1.10 \times 10^{-3}$ & $6.01 \times 10^{-3}$ & $7.15 \times 10^{-4}$ & 0.47 & 0.07 \\
\hline Glycolaldehyde $\left(\mathrm{HCOCH}_{2} \mathrm{OH}\right)$ & $1.87 \times 10^{-5}$ & $1.18 \times 10^{-5}$ & $2.52 \times 10^{-3}$ & $2.12 \times 10^{-3}$ & 135 & 142 \\
\hline Formic Acid $(\mathrm{HCOOH})$ & $6.59 \times 10^{-4}$ & $1.53 \times 10^{-4}$ & $4.84 \times 10^{-3}$ & $1.65 \times 10^{-3}$ & 7.34 & 3.03 \\
\hline Acetic Acid $\left(\mathrm{CH}_{3} \mathrm{COOH}\right)$ & $1.41 \times 10^{-2}$ & $1.19 \times 10^{-3}$ & $2.45 \times 10^{-2}$ & $5.69 \times 10^{-3}$ & 1.73 & 0.43 \\
\hline Formaldehyde (HCHO) & $1.65 \times 10^{-2}$ & $2.59 \times 10^{-3}$ & $2.42 \times 10^{-2}$ & $4.74 \times 10^{-3}$ & 1.47 & 0.37 \\
\hline Ammonia $\left(\mathrm{NH}_{3}\right)$ & $3.84 \times 10^{-2}$ & $9.69 \times 10^{-3}$ & $1.91 \times 10^{-2}$ & $2.65 \times 10^{-3}$ & 0.50 & 0.14 \\
\hline \multirow[t]{2}{*}{ Ozone $\left(\mathrm{O}_{3}\right)$} & $-5.13 \times 10^{-3}$ & $1.13 \times 10^{-3}$ & $1.02 \times 10^{-1}$ & $2.16 \times 10^{-2}$ & N/A & N/A \\
\hline & Ratioed to $\Delta \mathrm{CO}_{2}$ & & & & & \\
\hline Peroxy Acetyl Nitrate (PAN) & $4.75 \times 10^{-5}$ & $2.04 \times 10^{-5}$ & $5.10 \times 10^{-4}$ & $1.21 \times 10^{-4}$ & 10.74 & 5.27 \\
\hline Nitric Oxide (NO) & $8.21 \times 10^{-4}$ & $1.17 \times 10^{-4}$ & & & & \\
\hline Nitrogen Dioxide $\left(\mathrm{NO}_{2}\right)$ & $1.64 \times 10^{-3}$ & $9.00 \times 10^{-5}$ & & & & \\
\hline $\mathrm{NO}_{\mathrm{x}}$ (as NO) & $2.30 \times 10^{-3}$ & $3.62 \times 10^{-4}$ & $4.60 \times 10^{-4}$ & $2.30 \times 10^{-4}$ & 0.20 & 0.10 \\
\hline $\mathrm{PM}_{2.5}$ (light scattering) $)^{\mathrm{c}, \mathrm{d}}$ & $5.15 \times 10^{-3}$ & $1.33 \times 10^{-3}$ & $1.29 \times 10^{-2}$ & $1.89 \times 10^{-3}$ & 2.50 & 0.74 \\
\hline $\mathrm{OC}^{\mathrm{c}}$ & $2.22 \times 10^{-3}$ & $5.36 \times 10^{-4}$ & & & & \\
\hline $\mathrm{OA}^{\mathrm{c}}$ & $3.55 \times 10^{-3}$ & $8.57 \times 10^{-4}$ & $2.83 \times 10^{-3}$ & $2.52 \times 10^{-4}$ & 0.80 & 0.21 \\
\hline Sulfate $\left(\mathrm{SO}_{4}^{2-}\right)^{\mathrm{c}}$ & $3.58 \times 10^{-6}$ & $3.28 \times 10^{-6}$ & $6.72 \times 10^{-6}$ & $2.42 \times 10^{-6}$ & 1.88 & 1.85 \\
\hline Nitrate $\left(\mathrm{NO}_{3}^{-}\right)^{\mathrm{c}}$ & $9.61 \times 10^{-5}$ & $7.09 \times 10^{-5}$ & $3.87 \times 10^{-4}$ & $1.39 \times 10^{-4}$ & 4.03 & 3.30 \\
\hline Ammonium $\left(\mathrm{NH}_{4}^{+}\right)^{\mathrm{c}}$ & $6.00 \times 10^{-5}$ & $3.95 \times 10^{-5}$ & $2.34 \times 10^{-4}$ & $8.42 \times 10^{-5}$ & 3.90 & 2.93 \\
\hline Chloride $\left(\mathrm{Cl}^{-}\right)^{\mathrm{c}}$ & $4.97 \times 10^{-5}$ & $2.15 \times 10^{-5}$ & $1.33 \times 10^{-5}$ & $4.79 \times 10^{-6}$ & 0.27 & 0.15 \\
\hline $\mathrm{rBC}^{\mathrm{c}}$ & $7.83 \times 10^{-4}$ & $3.48 \times 10^{-4}$ & $7.30 \times 10^{-4}$ & $1.51 \times 10^{-4}$ & 0.93 & 0.46 \\
\hline fTC $\mathrm{rBC}^{\mathrm{e}}$ & 0.54 & 0.07 & 0.85 & 0.01 & 1.57 & 0.20 \\
\hline
\end{tabular}

a Error calculated as the standard error in the slope when no downwind NEMR data shown. Otherwise, uncertainty was calculated as the standard deviation in the mean of the source measurements collected.

$\mathrm{b}$ Downwind errors shown are an estimate of the uncertainty in individual downwind samples. The uncertainty in whether a trend is occurring is smaller.

c Reported as a mass ratio.

d Converting light scattering to $\mathrm{PM}_{2.5}$ with constant mass scattering efficiency not valid for aged smoke, see Sect. 3.3.

e Fraction of "thickly coated" rBC particles. All numbers reported as fractions.

initial slope-based $\Delta \mathrm{O}_{3} / \Delta \mathrm{CO}$ NEMR at time $t=0 \mathrm{~h}$ and the individual source measurements are not shown. The downwind error bar is an estimate of the uncertainty in the oldest individual downwind sample. As shown, $\Delta \mathrm{O}_{3} / \Delta \mathrm{CO}$ increased from $-5.13( \pm 1.13) \times 10^{-3}$ to $10.2( \pm 2.16) \times 10^{-2}$ in $\sim 4.5 \mathrm{~h}$ since smoke emission. Ozone production in a temperate forest BB plume in the Pacific Northwest of the US was noted previously by Hobbs et al. (1996), who reported that $\Delta \mathrm{O}_{3} / \Delta \mathrm{CO}$ reached $1.5 \times 10^{-2}$ in $30 \mathrm{~min}$. Akagi et al. (2011) assessed the literature on $\mathrm{O}_{3}$ measurements in $\mathrm{BB}$ plumes and concluded that $\mathrm{O}_{3}$ formation is ubiquitous in tropical BB plumes, but $\mathrm{O}_{3}$ formation or destruction can occur in extratropical BB plumes. Global models consistently conclude that $\mathrm{BB}$ is a major global source of tropospheric $\mathrm{O}_{3}$ (Fishman et al., 2003; Sudo and Akimoto, 2007). However, detailed plume scale studies find that reproducing detailed observations of $\mathrm{O}_{3}$ formation is difficult (Trentmann et al., 2005; Alvarado and Prinn, 2009). The data we report here provides a rare opportunity to test the photochemical mechanism in a model with low uncertainty in transport (M. Alvarado, personal communication, 2012). 


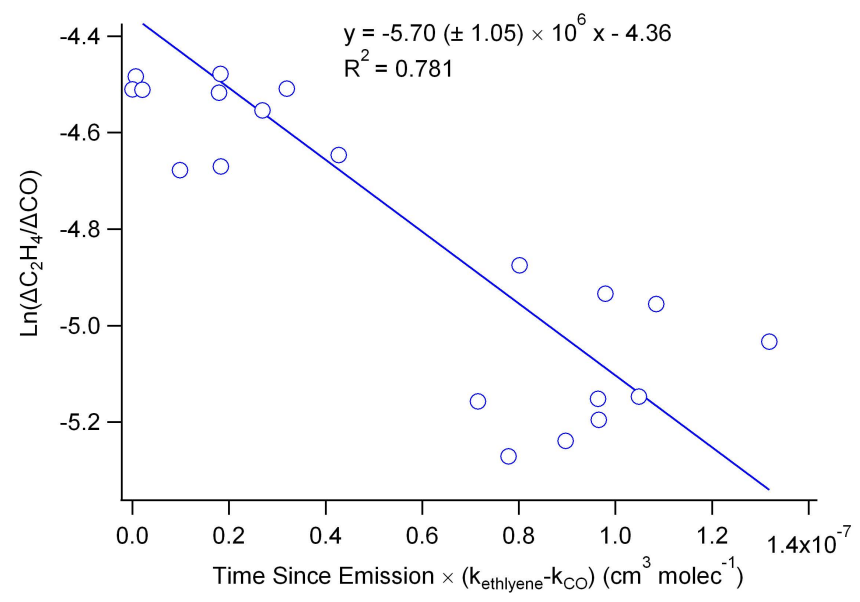

Fig. 6. $\operatorname{Ln}(\Delta$ ethylene/ $\Delta \mathrm{CO})$ vs. time since emission $(\mathrm{h}) \times\left(k_{\text {ethylene }}\right.$ $\left.-k_{\mathrm{CO}}\right)$. Average $\mathrm{OH}$ in the plume from $\sim 10: 30-15: 16 \mathrm{LT}$ is initially estimated from the absolute value of the slope $(5.70 \pm$ $1.05 \times 10^{6}$ molec cm$^{-3}$ ) and then corrected for $\mathrm{O}_{3}$ oxidation (see Sect. 3.2.2).

\subsubsection{Alkenes and estimated $\mathrm{OH}$}

Propylene mixing ratios dropped to levels near our detection limits within $\sim 30 \mathrm{~min}$ due to oxidation and dilution. The low signal-to-noise for $\mathrm{C}_{3} \mathrm{H}_{6}$ in the aged smoke made it difficult to quantify the decay rate. We also observed a rapid, but readily quantifiable, decrease in $\Delta \mathrm{C}_{2} \mathrm{H}_{4} / \Delta \mathrm{CO}$ (Fig. 6). We estimate the average $\mathrm{OH}$ concentration in the plume by considering both main oxidation processes for $\mathrm{C}_{2} \mathrm{H}_{4}$. Reaction with $\mathrm{OH}$ is the primary removal process $\left(k_{\text {ethylene }}=\right.$ $8.32 \times 10^{-12} \mathrm{~cm}^{3} \mathrm{molec}^{-1} \mathrm{~s}^{-1}$; Sander et al., 2006). Ozone oxidation is a competing reaction, but the loss of $\mathrm{C}_{2} \mathrm{H}_{4}$ is relatively small $(\sim 7.6 \%)$ given the lower rate constant $\left(k_{\text {ozone }}=1.7 \times 10^{-18} \mathrm{~cm}^{3}\right.$ molec $^{-1} \mathrm{~s}^{-1}$; Sander et al., 2006) and the typical $\mathrm{O}_{3}$ levels $(\sim 100 \mathrm{ppb})$ measured in the plume. As a first step, following the procedure derived by Hobbs et al. (2003), we fit a line to the decay of $\ln \left(\Delta \mathrm{C}_{2} \mathrm{H}_{4} / \Delta \mathrm{CO}\right)$ versus (time since emission) $\times\left(k_{\text {ethylene }}-k_{\mathrm{CO}}\right)$, where $k_{\mathrm{CO}}=$ $1.74 \times 10^{-13} \mathrm{~cm}^{3} \mathrm{molec}^{-1} \mathrm{~s}^{-1}$ (Sander et al., 2006) (Fig. 6). The slope in the plot implies an average $\mathrm{OH}$ concentration of $5.70( \pm 1.05) \times 10^{6} \mathrm{molec}^{-3}$. We reduce this average $\mathrm{OH}$ by $7.6 \%$ to account for the ethylene lost via the $\mathrm{O}_{3}$ oxidation channel resulting in a corrected $\mathrm{OH}$ estimate of $5.27( \pm 0.97) \times 10^{6} \mathrm{molec}^{-3}$. If we use only the highaltitude source samples it raises the initial $\Delta \mathrm{C}_{2} \mathrm{H}_{4} / \Delta \mathrm{CO}$ by $\sim 12 \%$ and that would also raise the $\mathrm{OH}$ estimate. The $\mathrm{OH}$ and $\mathrm{O}_{3}$ were unlikely to be constant in the plume and the background $\mathrm{CO}$ was as high as $22 \%$ of total $\mathrm{CO}$ in the most dilute sample. However, omitting the 2-4 most dilute samples or the oldest samples had only a small effect on the $\mathrm{OH}$ retrieval. Thus, we use the $\mathrm{O}_{3}$ corrected $\mathrm{OH}$ concentration of $5.27( \pm 0.97) \times 10^{6}$ molec $\mathrm{cm}^{-3}$ as a reasonable estimate of average $\mathrm{OH}$ in this plume.

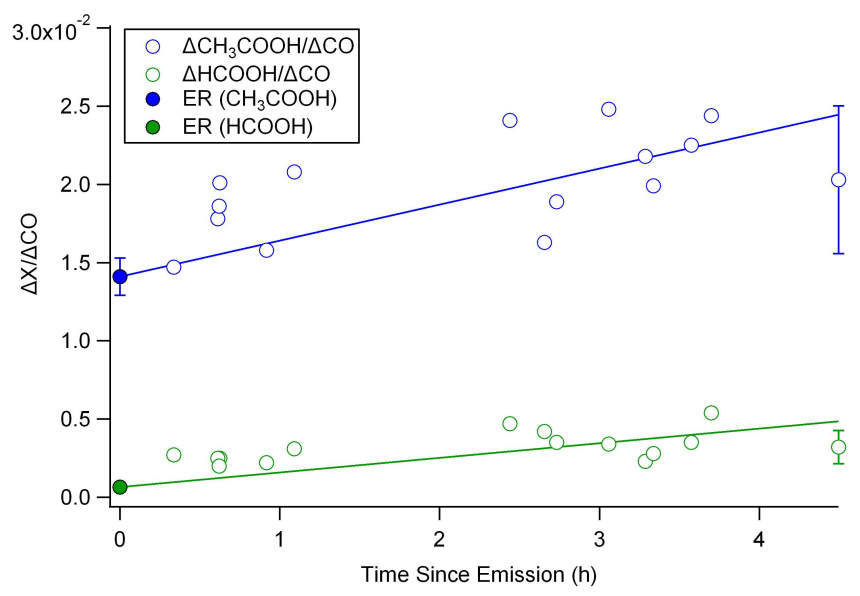

Fig. 7. Increase in $\Delta \mathrm{CH}_{3} \mathrm{COOH} / \Delta \mathrm{CO}$ (blue) and $\Delta \mathrm{HCOOH} / \Delta \mathrm{CO}$ (green) vs. time since emission (h). Individual source samples are not shown and we instead show ERs (solid blue and solid green circles, respectively) with an error bar reflecting the standard deviation in the mean of the ten source measurements. The $\mathrm{ER}(\mathrm{HCOOH})$ error bar is too small to be visible. Downwind error bars are an estimate of the uncertainty in the oldest individual downwind samples.

The $\mathrm{OH}$ levels largely govern the lifetime of VOCs and semi-volatile organic compounds (SVOCs) and the rate of formation of soluble or less volatile secondary products (Seinfeld and Pandis, 2006). Other oxidants such as $\mathrm{HO}_{2}$ and $\mathrm{RO}_{2}$ are also likely elevated in high $\mathrm{OH}$ environments (Mason et al., 2001). Similarly high concentrations of $\mathrm{OH}$, some greater than $10^{7}$ molec $\mathrm{cm}^{-3}$, have been inferred or measured in African and Mexican biomass burning plumes within the first hour of plume processing (Hobbs et al., 2003; Yokelson et al., 2009). The Williams Fire $\mathrm{OH}$ was likely lower than that in the African and Mexican plumes largely because of less intense solar radiation that would occur in midNovember at $\sim 35^{\circ} \mathrm{N}$ (Tables 3.7 and 3.9 in Finlayson-Pitts and Pitts, 2000). However, the Williams Fire $\mathrm{OH}$ is by no means depleted and likely contributes to the $\mathrm{O}_{3}$ production described above and many of the additional rapid postemission changes described in the following sections.

\subsubsection{Organic acids and aldehydes}

The aging plots for AFTIR and AMS species from this point forward (Fig. 7-11) show the ER of $\Delta X / \Delta \mathrm{CO}$ or $\Delta X / \Delta \mathrm{CO}_{2}$ at an estimated time since emission of $t=0 \mathrm{~h}$ with the $\mathrm{y}$ intercept of a best-fit trendline forced to the initial slopebased, fire-average ER, shown in Table 2. The uncertainty in the ER is an estimate of source variability from the $1 \sigma$ standard deviation in $\Delta X / \Delta C O$ in the ten source samples (described in Sect. 3.2). The uncertainty shown for the downwind samples is an estimate of the uncertainty in individual downwind samples. 
We measured formation of both acetic acid and formic acid over the course of $4.5 \mathrm{~h}$ (Fig. 7). The $\Delta \mathrm{CH}_{3} \mathrm{COOH} / \Delta \mathrm{CO}$ ratio increased from $1.41( \pm 0.119) \times 10^{-2}$ to $2.45( \pm 0.569)$ $\times 10^{-2}$ over $4.5 \mathrm{~h}$, a factor of $\sim 1.73 \pm 0.43$ (Table 2). Over the same aging period $\Delta \mathrm{HCOOH} / \Delta \mathrm{CO}$ increased from $6.59( \pm 1.53) \times 10^{-4}$ to $4.84( \pm 1.65) \times 10^{-3}$, a factor of $7.34 \pm 3.03$. Organic acids are a major component of biomass burning plumes and their post-emission behavior in BB plumes is summarized in Yokelson et al. (2009). The increase in acetic acid in the Williams Fire plume was slower than the rapid increase in $\Delta \mathrm{CH}_{3} \mathrm{COOH} / \Delta \mathrm{CO}$ to $\sim 0.09$ in less than $1 \mathrm{~h}$ seen in African savanna fire plumes (Yokelson et al., 2003a). However, formic acid did not increase downwind of those savanna fires. In the Williams Fire plume, and many other studies, the post-emission increases in organic acids were greater than the amount of known precursors, which suggests that organic acids may be the oxidation products of currently unidentified co-emitted NMOC (Yokelson et al., 2009). At higher RH, heterogeneous reactions may also be a source of formic acid (Tabazadeh et al., 1998).

The glycolaldehyde NEMR to $\triangle \mathrm{CO}$ increases by a small total amount downwind, but with a high uncertainty (Table 2). Glycolaldehyde is a major product of cellulose pyrolysis (Richards, 1987; Radlein et al., 1991) and smoldering combustion (Yokelson et al., 1997), and also a known byproduct of hydroxyl initiated oxidation of ethylene and isoprene. Being highly water soluble, aqueous-phase reactions of glycolaldehyde may be important in the formation of secondary organic aerosol (Perri et al., 2009) via the formation of lower volatility compounds. Formaldehyde can be produced post-emission in plumes from the oxidation of NMOC, but also lost by photolysis and reaction with $\mathrm{OH}$ or $\mathrm{HO}_{2}$. $\mathrm{HCHO}$ photolysis is an important source of $\mathrm{OH}$ (Mason et al., 2001). In the Williams Fire plume, $\Delta \mathrm{HCHO} / \Delta \mathrm{CO}$ increased during the first hour after emission and then leveled off (Table 2, graph not shown).

\subsubsection{Gas-particle conversion and formation of reservoir species: nitrogen-containing compounds}

Fitting an exponential decay to the molar ratio of $\Delta \mathrm{NH}_{3} / \Delta \mathrm{CO}$ (not shown) implies that roughly half of the initial $\mathrm{NH}_{3}$ was lost in $\sim 4.5 \mathrm{~h}$. Much of the decrease between the downwind NEMRs and the ER occurs in the first hour following emission, suggesting rapid, initial $\mathrm{NH}_{3}$ removal by chemical and physical aging. In Fig. 8 we compare the decrease in the molar ratio of $\Delta \mathrm{NH}_{3} / \Delta \mathrm{CO}_{2}$ (derived from AFTIR data) to the molar increase in $\Delta \mathrm{NH}_{4}^{+} / \Delta \mathrm{CO}_{2}$ (measured by the AMS and NDIR) over $4 \mathrm{~h}$, which is the approximate time since emission of the oldest AMS sample. The fit implies a significant decay in $\Delta \mathrm{NH}_{3} / \Delta \mathrm{CO}_{2}$ along with a clear increase in $\Delta \mathrm{NH}_{4}^{+} / \Delta \mathrm{CO}_{2}$ (Fig. $8 \mathrm{a}$ and b, respectively). We note the apparent high variability in the source measurements for $\mathrm{NH}_{3}$ and emphasize that this is an artifact arising from compression to "time zero" of all
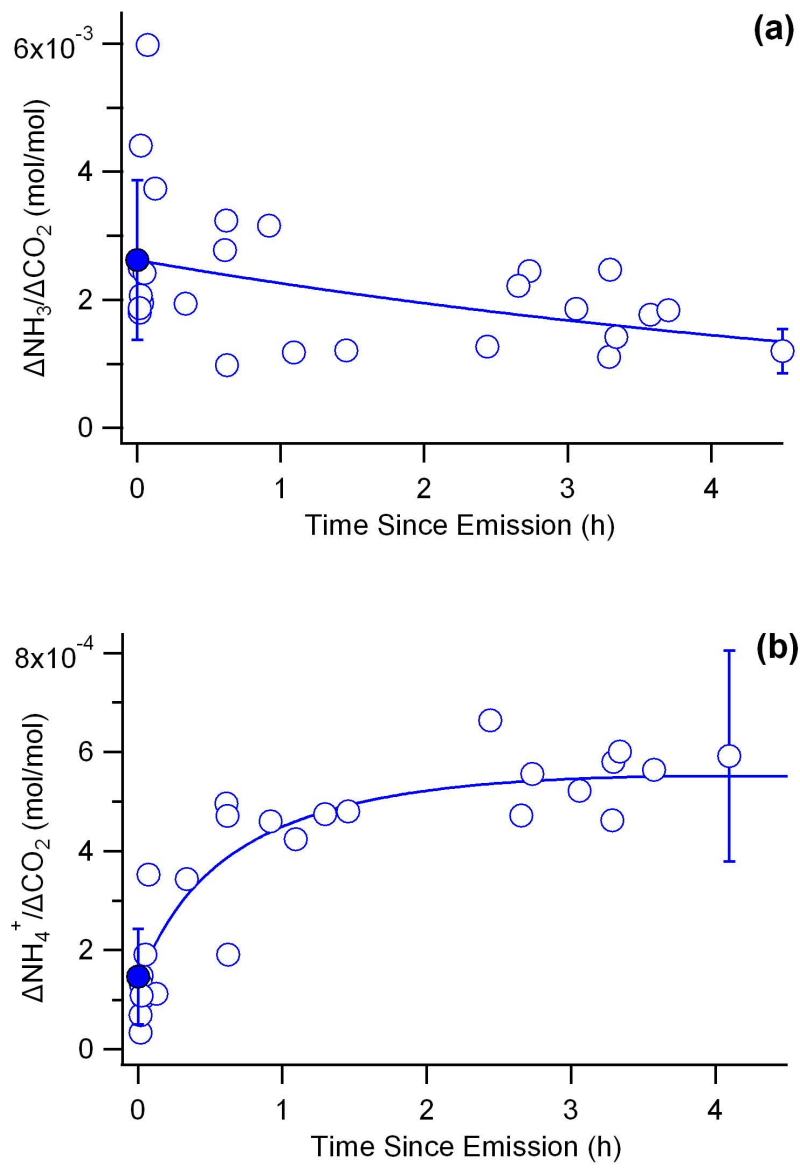

Fig. 8. (a) $\Delta \mathrm{NH}_{3} / \Delta \mathrm{CO}_{2}$ molar ratio vs. time since emission (h). The decay in $\Delta \mathrm{NH}_{3} / \Delta \mathrm{CO}$ vs. time since emission is slightly better correlated, but we show $\Delta \mathrm{NH}_{3} / \Delta \mathrm{CO}_{2}$ here for direct comparison to the AMS data in Fig. 8b. Points were fit to an exponential trendline. (b) $\Delta \mathrm{NH}_{4}^{+} / \Delta \mathrm{CO}_{2}$ molar ratio vs. time since emission (h). Note difference in y-scale. Points were fit to a logarithmic trendline. For both (a) and (b), ERs (solid circles) are shown with an error bar reflecting the standard deviation in the mean of the ten source measurements. We retain all source samples to show the inherent variability in source measurements. Downwind error bars are an estimate of the uncertainty in the oldest individual downwind samples.

the $\Delta \mathrm{NH}_{3} / \Delta \mathrm{CO}_{2}$ ER samples, which increased in monotonic fashion from the beginning to end of the source sampling period. The $\Delta \mathrm{NH}_{4}^{+} / \Delta \mathrm{CO}_{2}$ ratio increases post emission by a factor of $3.90 \pm 2.93$ (Table 2), with this growth accounting for a fraction of $0.36 \pm 0.31$ of the gaseous ammonia lost on a molar basis. $\mathrm{NH}_{3}$ reacts quickly with $\mathrm{HNO}_{3}$ to form solid $\mathrm{NH}_{4} \mathrm{NO}_{3}$ and $\mathrm{NH}_{3}$ may also react with organic acids to form other ammonium compounds in both the solid and liquid phases (though the low RH in the Williams Fire plume favors reactions in the solid phase, see below). However, since only about one-third of the ammonia lost was detected as ammonium, other loss processes must be considered. Ammonia removal pathways competing with 
ammonium formation include the oxidation of $\mathrm{NH}_{3}$ by $\mathrm{OH}$ (Dentener and Crutzen, 1994), but this reaction proceeds at a relatively slow rate at typical plume concentrations $(k=$ $1.6 \times 10^{-13} \mathrm{~cm}^{3} \mathrm{molec}^{-1} \mathrm{~s}^{-1}$; Sander et al., 2006) and would not significantly reduce the amount of free ammonia over the course of $4 \mathrm{~h}$. No precipitation or even clouds impacted the plume so wet deposition was not a factor, but a plausible loss process was the dry deposition of $\mathrm{NH}_{3}$ since it is a "sticky" molecule known to adhere on surface sites (Yokelson et al., 2003b) and undergo dry deposition readily (Seinfeld and Pandis, 2006). Dry deposition of $\mathrm{NH}_{3}$ to any water coating that could be present on the surface of aerosol particles can remove ammonia from the gaseous state (Asman et al., 1998), however, over $99 \%$ of gaseous ammonia absorbing into the liquid phase would exist as ammonium and be detected by the AMS. Dry particles can also provide surface sites for ammonia adsorption to occur. However, $\mathrm{NH}_{3}$ adsorbed to particles would also likely be detected by the AMS as ammonium, since particulate ammonium fragments to $m / z 17,16$, and 15 , following vaporization and ionization. Thus, it is not likely that dry deposition accounts for the majority of the observed $\mathrm{NH}_{3}$ loss.

Other plausible fates of $\mathrm{NH}_{3}$ may have involved the formation of new ammonium nitrate particles at the plume temperatures of $12-15^{\circ} \mathrm{C}$ or condensation of ammonium nitrate onto existing particles that, in either case, are outside the most efficient detection range of the AMS $(50-800 \mathrm{~nm})$. Due to the low RH environment of the Williams Fire, nascent particles were probably not water coated and grew very slowly. While Semuniuk et al. (2007) observed rapid hygroscopic growth of fresh smoke particles in the range of $55-100 \%$ RH, the Williams Fire RH range of $\sim 11-26 \%$ is much lower, and also lower than the deliquescence and efflorescence points of most common salts (>60\%) (Tang and Munkelwitz, 1993, 1994a, b). Thus, new particle formation and condensation on those particles could have been occurring without being detected if particles were growing slow enough to evade AMS detection even after several hours since emission. We also can not discount the possibility that ammonium nitrate was incorporated in particles that were larger than $800 \mathrm{~nm}$.

We roughly compare the Williams Fire observations with those in a Yucatan BB plume in a 70-100\% RH environment where ammonium formation accounted for roughly $32 \%$ of the estimated starting $\mathrm{NH}_{3}$ in just $1.4 \mathrm{~h}$ (Yokelson et al., 2009). Ammonium formation accounted for only $\sim 13 \%$ of the measured initial $\mathrm{NH}_{3}$ over $1.4 \mathrm{~h}$ in the Williams Fire plume. Faster ammonium formation accounting for more of the initial ammonia may have occurred in the Yucatan due to increased deposition to wetter particles, faster particle growth, or faster $\mathrm{HNO}_{3}$ formation under tropical photochemical conditions.

Figure 9 shows the decrease in $\Delta \mathrm{NO}_{\mathrm{x}} / \Delta \mathrm{CO}_{2}$ (blue) and corresponding increases in both $\Delta \mathrm{NO}_{3}^{-} / \Delta \mathrm{CO}_{2}$ (green) and $\Delta \mathrm{PAN} / \Delta \mathrm{CO}_{2}$ (light blue) during $4 \mathrm{~h}$ after emission. Pro-

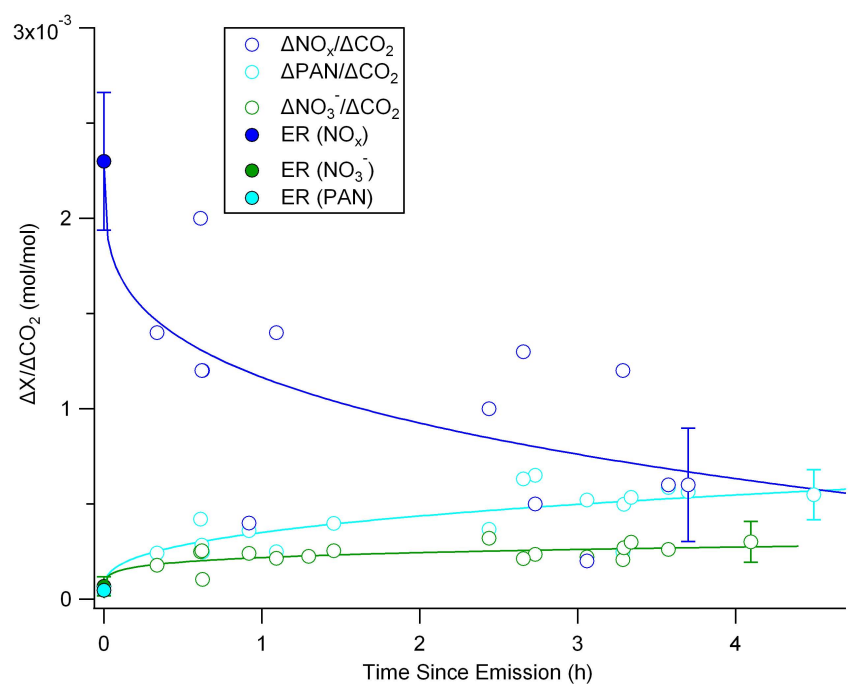

Fig. 9. $\triangle \mathrm{NO}_{\mathrm{x}}$ (blue), $\triangle \mathrm{PAN}$ (light blue), and $\Delta \mathrm{NO}_{3}^{-}$(green) ratioed to $\Delta \mathrm{CO}_{2}$ (molar) vs. time since emission (h). Corresponding emission ratios (ER) are shown as solid blue, light blue, and green circles, respectively. ER error bars show the standard deviation in the mean of the ten source measurements. The ER(PAN) error bar is too small to be visible. Downwind error bars are an estimate of the uncertainty in oldest individual downwind samples. Points were fit to logarithmic trendlines.

cesses that remove $\mathrm{NO}_{\mathrm{x}}$ from the plume or transfer it to reservoir species such as PAN or alkyl nitrates are important, as $\mathrm{NO}_{\mathrm{x}}$ is a precursor for $\mathrm{O}_{3}$ formation. A major $\mathrm{NO}_{\mathrm{x}}$ loss process is the association reaction of $\mathrm{OH}$ with $\mathrm{NO}_{2}$ to form $\mathrm{HNO}_{3}$, which can condense to form particle nitrate. At the average temperature and pressure of the Williams Fire plume, the $\mathrm{NO}_{2}$ association reaction occurs with a pseudo second order rate constant of $1.04 \times 10^{-11} \mathrm{~cm}^{3} \mathrm{molec}^{-1} \mathrm{~s}^{-1}$ (Sander et al., 2006) and a pseudo first order rate constant (using our derived average $\mathrm{OH}$ concentration from Sect. 3.2.2) of $5.47 \times 10^{-5} \mathrm{~s}^{-1}$ for an $\mathrm{NO}_{2}$ lifetime of $\sim 5.1 \mathrm{~h}$. Thus, in the $4 \mathrm{~h}$ that we monitored the plume this reaction would be expected to convert roughly $54 \%$ of the initial $\mathrm{NO}_{\mathrm{x}}$ to $\mathrm{HNO}_{3}$ (and potentially nitrate). Gas-phase nitric acid was not measured in the Williams Fire plume, however other studies have reported that there was no measureable enhancement of gas-phase $\mathrm{HNO}_{3}$ in any of the BB plumes measured (Yokelson et al., 2009; Alvarado et al., 2010). The reason for this is likely because $\mathrm{HNO}_{3}$ can react rapidly with $\mathrm{NH}_{3}$ to form $\mathrm{NH}_{4} \mathrm{NO}_{3}$ (as discussed above), and $\mathrm{HNO}_{3}$ (or $\mathrm{NH}_{4} \mathrm{NO}_{3}$ ) have high deposition velocities to wet and dry surfaces. In the Williams Fire, all these processes could theoretically remove $\mathrm{HNO}_{3}$ from the plume, but loss by deposition to wet surfaces is unlikely due to the low RH.

The $\Delta \mathrm{NO}_{3}^{-} / \Delta \mathrm{CO}_{2}$ molar ratio was initially very low, but secondary formation of nitrate occurred rapidly as can be seen from the logarithmic trendline in Fig. 9 (green). The trend in $\Delta \mathrm{NO}_{3}^{-} / \Delta \mathrm{CO}_{2}$ is similar to that of $\Delta \mathrm{NH}_{4}^{+} / \Delta \mathrm{CO}_{2}$, 
suggesting an initial burst in these inorganic particle species in the first hour since emission. After $4 \mathrm{~h}$, AMS-detected nitrate accounted for only $\sim 22 \%$ of the $\mathrm{HNO}_{3}$ (molar basis) predicted to form based on our derived average $\mathrm{OH}$ concentration. The unaccounted for $\mathrm{HNO}_{3}$ comprises $\sim 42 \%$ of the initial $\mathrm{NO}_{\mathrm{x}}$. Some of the missing $\mathrm{HNO}_{3}$ could have been present in the plume as nitrate in particles that dissociated in the AMS inlet. However, inlet losses in the AMS due to evaporation probably did not significantly affect our measurements given the modest temperature increase within the aircraft $\left(3-11^{\circ} \mathrm{C}\right)$ and the inlet residence time of $\sim 2.5 \mathrm{~s}$. Huffman et al. (2009) outfitted their airborne AMS inlet with a thermodenuder and measured nitrate evaporation rates of $\sim 0.2 \% \mathrm{C}^{-1} \mathrm{~s}^{-1}$. As mentioned above, it is plausible that $\mathrm{NH}_{3}$ and $\mathrm{HNO}_{3}$ formed new (or condensed on existing) particles that were outside the AMS size detection range. Missing $\mathrm{HNO}_{3}$ ratioed to missing ammonium $(\sim 1.3)$ does suggest that small or large particles containing ammonium nitrate could account for substantial undetected signal due to both ions, but that some gas phase $\mathrm{HNO}_{3}$ may have also been present that we were unable to measure with the instruments onboard the Twin Otter. The possible importance of ammonium nitrate in small particles in fresh BB plumes is further supported by the observations of Yokelson et al. (2009). In that study, $49 \pm 16 \%$ of $\mathrm{HNO}_{3}$ expected to form from the reaction of $\mathrm{NO}_{2}$ and $\mathrm{OH}$ was observed as nitrate in a high $\mathrm{RH}$ BB plume after $1.4 \mathrm{~h}$ since emission. Further, $\mathrm{HNO}_{3}$ was measured, but not elevated above background in the plume. Thus, in that high RH environment (70-100\%), particle growth could have been approximately six times faster than in the Williams Fire, but still slow enough that half the nitrate mass was in particles too small to detect with the AMS.

Formation of reservoir species such as PAN also causes $\mathrm{NO}_{\mathrm{x}}$ to decrease from its initial level (Seinfeld and Pandis, 2006; Alvarado et al., 2010). PAN ratioed to $\mathrm{CO}_{2}$ shows rapid initial growth (Fig. 9, light blue) similar to nitrate and ammonium. Overall, $\triangle \mathrm{PAN} / \Delta \mathrm{CO}_{2}$ increases by a factor of $10.7 \pm 5.3$ in $4 \mathrm{~h}$ since emission (Table 2) and accounts for $22 \pm 6 \%$ of initial $\mathrm{NO}_{\mathrm{x}}$ on a molar basis after $4 \mathrm{~h}$. Thus, the total $\mathrm{NO}_{\mathrm{x}}$ decrease due to the observed PAN formation plus the calculated $\mathrm{NO}_{\mathrm{x}}$ loss via reaction with $\mathrm{OH}$ is $76 \%$, which agrees remarkably well with the observed total $\mathrm{NO}_{\mathrm{x}}$ decrease of $\sim 80 \%$ seen in Fig. 9. However, the uncertainties are high enough that formation of other reservoir species such as gasphase $\mathrm{HNO}_{3}$, alkyl nitrates, or other peroxy nitrates could also be significant. The decrease in $\Delta \mathrm{NO}_{\mathrm{x}} / \Delta \mathrm{CO}_{2}$ over $4 \mathrm{~h}$ shows how $\mathrm{NO}_{2}$, which is available for photolysis and $\mathrm{O}_{3}$ formation in the fresh plume, was quickly converted to PAN, which can then be transported considerable distances before thermally decomposing and releasing $\mathrm{NO}_{2}$ for $\mathrm{O}_{3}$ production far from the source (Val Martin et al., 2006). After $4 \mathrm{~h}$ since emission, the excess PAN is roughly double the excess $\mathrm{NO}_{3}^{-}$. Alvarado et al. (2010) also observed a PAN/nitrate ratio of 2 in boreal forest fire plumes of qualitatively sim- ilar time since emission. In the case of the Williams Fire, we are hesitant to interpret the PAN/nitrate ratio as a measure of the $\triangle \mathrm{PAN} / \triangle \mathrm{HNO}_{3}$ branching ratio since the nitrate fails to account for all the $\mathrm{NO}_{\mathrm{x}}$ calculated to be converted to $\mathrm{HNO}_{3}$. Smoke plume simulation studies by Mason et al. (2001) found that PAN formation becomes increasingly dominant over $\mathrm{HNO}_{3}$ formation further downwind. While we cannot account for all $\mathrm{NO}_{\mathrm{x}}$ lost to the $\mathrm{HNO}_{3}$ channel, we do observe that the $\triangle \mathrm{PAN} / \Delta \mathrm{NO}_{3}^{-}$ratio grew by a factor of $\sim 2$ over the course of $4 \mathrm{~h}$ since emission.

\subsubsection{Evolution of sulfate and chloride}

The $\Delta \mathrm{SO}_{4}^{2-} / \Delta \mathrm{CO}_{2}$ mass ratio steadily increased nearly twofold from $3.58( \pm 3.28) \times 10^{-6}$ to $6.72( \pm 2.42) \times 10^{-6}$ in $4 \mathrm{~h}$ since emission (Table 2, Fig. 10a). The high uncertainty reported is due to the large variability in the source measurements, but a clear increasing trend with time since emission is evident. Unlike the rapid initial formation of nitrate and ammonium, the sulfate growth is gradual. This is expected since $\mathrm{OH}$ reacts relatively slowly with $\mathrm{SO}_{2}$ $\left(8.8 \times 10^{-13} \mathrm{~cm}^{3} \mathrm{molec}^{-1} \mathrm{~s}^{-1}\right.$, Sander et al., 2006), and the plume was too dry for aqueous sulfate formation to be significant. In a Yucatan BB plume characterized by high initial emissions of $\mathrm{SO}_{2}$ and high $\mathrm{RH}$, Yokelson et al. (2009) observed that $\Delta \mathrm{SO}_{4}^{2-} / \Delta \mathrm{CO}$ increased by a factor of $8.8 \pm 2.7$ in just $1.4 \mathrm{~h}$. This suggests that the higher $\mathrm{RH}, \mathrm{OH}$, and initial $\mathrm{SO}_{2}$ contributed to much faster sulfate formation in the Yucatan plume. In addition, Yokelson et al. (2009) observed $\Delta \mathrm{NH}_{4}^{+}$to be about equal to the sum of twice the $\Delta \mathrm{SO}_{4}^{2-}$ plus the $\Delta \mathrm{NO}_{3}^{-}$(on a molar basis) in that plume. Additionally, sulfate had accounted for $\sim 60 \%$ as much negative charge as nitrate. For the Williams Fire, a graph of $\Delta \mathrm{NO}_{3}^{-}$vs. $\Delta \mathrm{NH}_{4}^{+}$ on a molar basis (Fig. 10b) yields a slope of $0.466 \pm 0.010$ $\left(R^{2}=0.95\right)$, which is almost identical to the ratio observed in the Yucatan plume, but the Williams Fire $\Delta \mathrm{NO}_{3}^{-}$to $\Delta \mathrm{SO}_{4}^{2-}$ molar ratio was $>100$. This suggests sulfate was not a significant counter-ion for ammonium in this plume and that the particle ammonium was pairing with negative ions other than nitrate and sulfate.

The $\Delta \mathrm{Cl}^{-} / \Delta \mathrm{CO}_{2}$ ratio decreases with time since emission in a well correlated fashion (Fig. 10c), except for one sample collected during Flight 1. Chloride may decrease because it is replaced by other anions such as nitrate as they form (Posfai et al., 2003; Li et al., 2003) although nitrate formation greatly exceeds chloride losses. The fate of the chloride released from the particles is unknown, but it is unlikely that most of the released chloride constitutes a rapid source of $\mathrm{Cl}$ atoms. The $\mathrm{Cl}$ atom has an appreciable rate coefficient with $\mathrm{C}_{2} \mathrm{H}_{2}$ (Tabazadeh et al., 2004), and we did not observe a change in $\Delta \mathrm{C}_{2} \mathrm{H}_{2} / \Delta \mathrm{CO}$ over $4.5 \mathrm{~h}$ since emission. In any case, the amount of $\Delta \mathrm{Cl}^{-}$is insufficient to pair with a significant fraction of the $\Delta \mathrm{NH}_{4}^{+}$during the later stages of plume evolution (Fig. 10d) and the total charge from measured inorganic anions $\left(\mathrm{Cl}^{-}+\right.$twice sulfate + nitrate $)$is only sufficient 

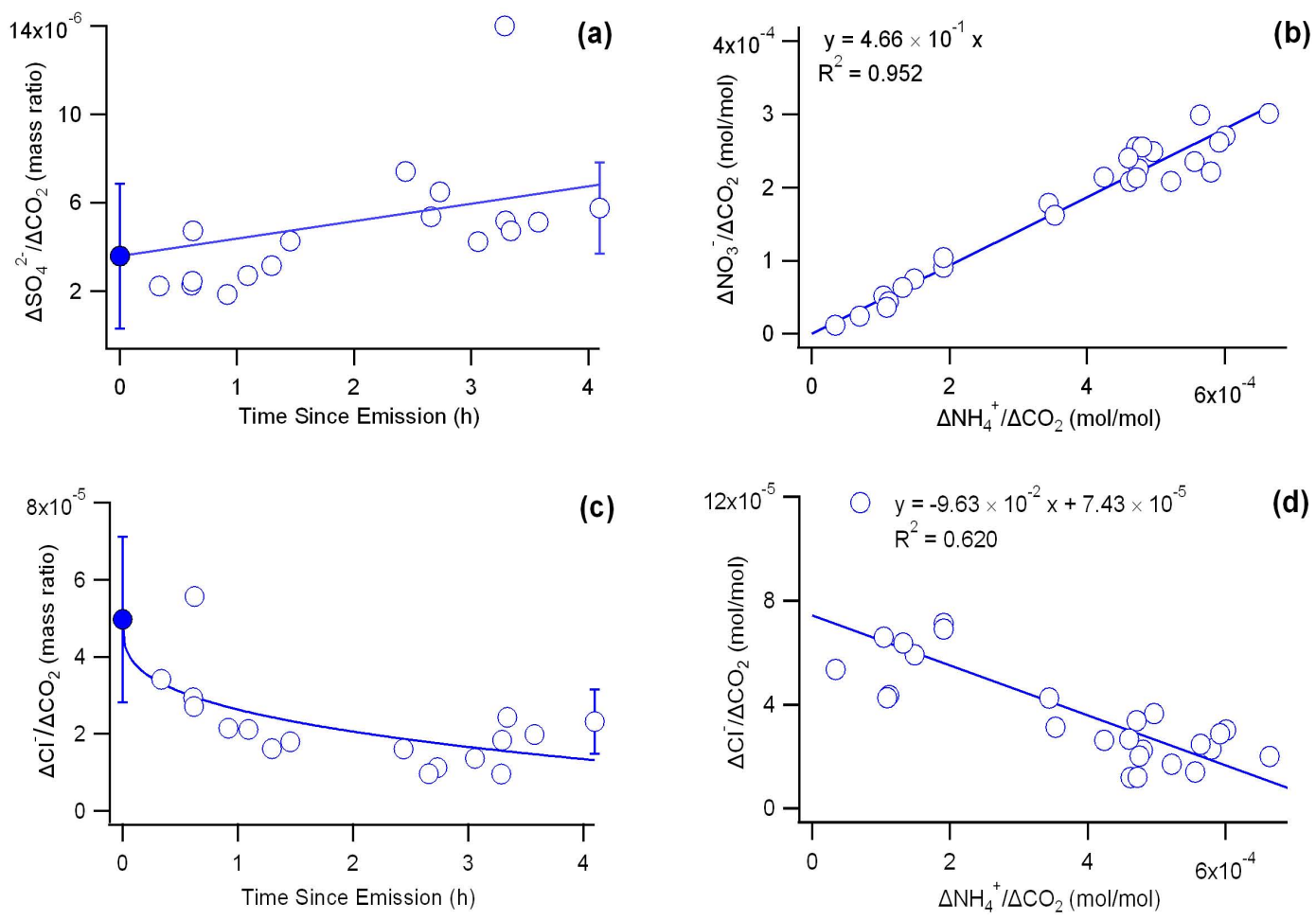

Fig. 10. (a) $\Delta \mathrm{SO}_{4}^{2-} / \Delta \mathrm{CO}_{2}$ mass ratio vs. time since emission (h). (b) $\Delta \mathrm{NO}_{3}^{-} / \Delta \mathrm{CO}_{2}$ vs. $\Delta \mathrm{NH}_{4}^{+} / \Delta \mathrm{CO}_{2}$ on a molar basis. (c) $\Delta \mathrm{Cl}^{-} / \Delta \mathrm{CO}_{2}$ mass ratio vs. time since emission (h) fit to a power curve. (d) $\Delta \mathrm{Cl}^{-} / \Delta \mathrm{CO}_{2}$ vs. $\Delta \mathrm{NH}_{4}^{+} / \Delta \mathrm{CO}_{2}$ on a molar basis. In both (a) and (c) individual source samples are not shown and we instead show ERs (solid circles) with an error bar that is the standard deviation in the mean of the ten source measurements. Downwind error bars are an estimate of the uncertainty in oldest individual downwind samples.

to pair with $\sim 50 \%$ of the ammonium suggesting that the latter may also be pairing with unmeasured organic anions such as formate or acetate. The possible significance of organic anions is further supported by the fact that ammonium is not the only significant cation in BB plumes. For instance high levels of $\mathrm{K}^{+}$are normally reported in $\mathrm{BB}$ plumes and it is often used as a tracer for BB (Zhang et al., 2010).

\subsection{Evolution of light scattering and organic aerosol}

The trends in light scattering and organic aerosol (OA) were similar when we used source ER based on all the source samples or only those obtained at high altitudes. In general, $\Delta b_{\text {scat }}$ (or $\Delta$ light scattering) $/ \Delta \mathrm{CO}_{2}$ increased by a factor of $2.50 \pm 0.74$ (Table 2) and $\Delta b_{\text {scat }} / \Delta \mathrm{CO}$ increased by a similar factor of $2.45 \pm 0.55$ over the course of $4 \mathrm{~h}$. If we assume a constant conversion factor with time since emission (208 $800 \mu \mathrm{g} \mathrm{sm}^{-2}$, Sect. 2.1.4) between scattering (at $530 \mathrm{~nm}$ wavelength) and $\mathrm{PM}_{2.5}$, then this implies a factor of $\sim 2.50$ increase in $\Delta \mathrm{PM}_{2.5}$ (ratioed to $\Delta \mathrm{CO}_{2}$ ) as shown in Fig. 11. This increase is comparable to the $2.6 \pm 1.5$ growth factor in $\Delta$ light scattering/ $\Delta \mathrm{CO}$ seen in $\sim 1.4 \mathrm{~h}$ in an isolated $\mathrm{BB}$ plume in the Yucatan (Yokelson et al., 2009). In the case of the Yucatan plume, the particle growth inferred from increased scattering (derived using the same methodology as above) was confirmed by a growth factor of $\sim 2.4$ in the sum of species measured by AMS ratioed to $\triangle \mathrm{CO}$. The growth in AMS species was driven mostly by significant secondary OA (SOA) formation in the Yucatan plume, with an increase in $\Delta \mathrm{OA} / \Delta \mathrm{CO}$ of $2.3 \pm 0.85$ in $1.4 \mathrm{~h}$ (Yokelson et al., 2009).

However, in the Williams Fire, although light scattering increased significantly with time since emission, $\triangle \mathrm{OA} / \Delta \mathrm{CO}_{2}$ dropped initially, followed by a slow increase after $\sim 1.5-2 \mathrm{~h}$. The net result was a decrease in $\Delta \mathrm{OA} / \Delta \mathrm{CO}_{2}$ by a factor of $0.80 \pm 0.21$ when assessing all samples up to $4 \mathrm{~h}$ since emission (Table 2). In addition, the assumption of a constant ratio between light scattering and particle mass would imply that $\Delta \mathrm{OA} / \Delta \mathrm{PM}_{2.5}$ decreased from $0.69 \pm 0.24$ to $0.22 \pm 0.04$ after $4 \mathrm{~h}$ since emission. This is inconsistent with the change in OA normalized by the sum of the species measured by the AMS, which decreased from a fraction of 0.94 to 0.82 over this $4 \mathrm{~h}$ time period (where the sum of the measured AMS species should account for approximately $0.8-0.9$ of $\mathrm{PM}_{2.5}$ mass). Thus it seems unlikely that the relationship between light scattering and $\mathrm{PM}_{2.5}$ was constant with aging. We therefore cannot determine changes in $\mathrm{PM}_{2.5}$ over the $4 \mathrm{~h}$ following emission using a constant conversion factor.

Next we describe a plausible physical model to rationalize both the Yucatan and Williams Fire observations. It is possible that the increased light scattering in the Yucatan 


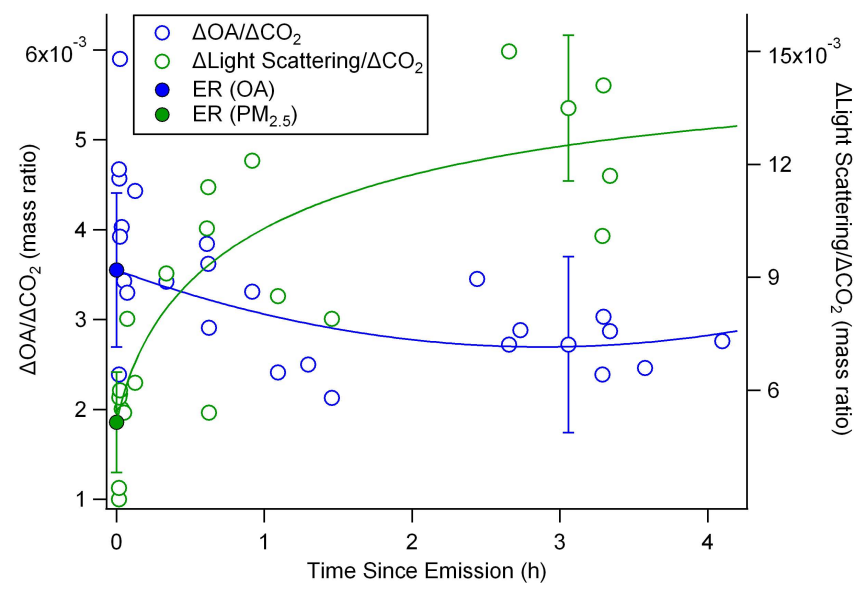

Fig. 11. $\Delta$ Light scattering/ $\Delta \mathrm{CO}_{2}$ (green) and $\Delta \mathrm{OA} / \Delta \mathrm{CO}_{2}$ (blue) mass ratios are shown vs. time since emission (h). ER( $\mathrm{PM}_{2.5}$ ) (solid green circle) and ER(OA) (solid blue circle) are shown with error bars depicting the standard deviation in the mean of the ten source measurements. We show all the source samples to illustrate the variability in the source measurements. The log-normal ( $\Delta$ light scattering/ $\left.\Delta \mathrm{CO}_{2}\right)$ and second order polyfit $\left(\Delta \mathrm{OA} / \Delta \mathrm{CO}_{2}\right)$ trendlines shown best correlate with the data. Error bars shown on downwind samples are an estimate of the uncertainty in individual downwind samples. $\Delta$ Light scattering $/ \Delta \mathrm{CO}_{2}$ is shown converted to the mass ratio $\Delta \mathrm{PM}_{2.5} / \Delta \mathrm{CO}_{2}$ under the assumption that the ratio between $b_{\text {scat }}$ and $\mathrm{PM}_{2.5}$ is constant with time since emission. The assumption that the conversion between $b_{\text {scat }}$ and $\mathrm{PM}_{2.5}$ is constant with smoke age would imply an unrealistic $\Delta \mathrm{OA} / \Delta \mathrm{PM}_{2.5}$ of $<25 \%$ at a plume age of $4 \mathrm{~h}$. The increase in light scattering during the first $1.5 \mathrm{~h}$ since emission is probably due to particle growth via coagulation and then chiefly by condensation soon thereafter (Sect. 3.3).

plume was due to growth in the average particle diameter towards the measurement wavelength. The diameter growth could have occurred by both condensation and coagulation and the mass growth confirmed by the AMS in the Yucatan plume implies that condensation dominated over evaporation and coagulation. The similar increase in light scattering and the AMS mass may have been coincidental. In contrast, the increased scattering in the Williams Fire plume could have been caused by growth in average particle diameter mainly due to coagulation while, in contrast to the Yucatan plume, evaporation of organics initially exceeded condensation. A simple polydisperse coagulation scenario can explain the Williams Fire observations. We start by assuming that, at the source, there are many more particles in the $50-100 \mathrm{~nm}$ diameter range (which do not contribute substantially to the measured scattering) than particles in the 100 $300 \mathrm{~nm}$ diameter range. Collisions between the small and large particles then decrease the small particle number (without reducing scattering), but increase the average diameter of the larger particles towards the measurement wavelength $(530 \mathrm{~nm}$ in this case), thus increasing scattering efficiency according to Mie theory. Coagulation may also account for most of the increase in the fraction of thickly coated rBC particles we observed in the Williams Fire plume (discussed in the next section). At the same time, $\sim 20-30 \%$ of the OA could have evaporated causing the small decrease in OA that is observed. We note that this explanation invokes the presence of large quantities of small $(\sim 50-100 \mathrm{~nm})$ particles in the fresh smoke. Particles $\sim 30-50 \mathrm{~nm}$ in diameter dominated the number distribution in some laboratory BB studies (Hosseini et al., 2010; Chakrabarty et al., 2006), but there are no airborne measurements of particles in this size range in BB plumes to our knowledge.

We also note that the probability of observing fast, initial coagulation was much higher in the Williams Fire plume. The Yucatan plume was from a small fire and the freshest sample was at an altitude of $1700 \mathrm{~m}$ a.g.l. when the smoke was already $10-30 \mathrm{~min}$ old and the $\Delta \mathrm{CO}$ reading on a fast 1 -s instrument was $823 \mathrm{ppb}$. We did not have 1-s $\mathrm{CO}$ instrumentation during the Williams Fire, but our 2-s $\mathrm{CO}_{2}$ instrument observed a maximum $\Delta \mathrm{CO}_{2}$ of $390 \mathrm{ppm}$. The $\Delta \mathrm{CO}_{2}$ maximum multiplied by the fire-average $\Delta \mathrm{CO} / \Delta \mathrm{CO}_{2}$ ratio (0.0713, Table 2$)$ for the Williams Fire implies a maximum $\Delta \mathrm{CO}$ in our freshest smoke of at least $28 \mathrm{ppm}$. Thus, the smoke at the beginning of the aging sequence observed in the Williams Fire plume was about 34 times more concentrated than at the beginning of the observations for the Yucatan plume and coagulation would likely have been about 1000 times faster.

We point out that the decrease in $\Delta \mathrm{OA} / \Delta \mathrm{CO}_{2}$ in the Williams Fire plume continues only to the samples collected around $\sim 1.5-2 \mathrm{~h}$ following emission. After this time, $\Delta \mathrm{OA} / \Delta \mathrm{CO}_{2}$ increases at about the same rate as scattering suggesting that some of the organics that initially evaporated from the particles may have undergone homogeneous oxidation in the gas-phase leading to products with lower vapor pressure that then recondensed on the particles (Robinson et al., 2007). In any case, condensation is evidently dominating over evaporation from $1.5-2 \mathrm{~h}$ onward.

The OA evolution observed in the Yucatan plume is more likely to be the norm for most global biomass burning than the OA evolution observed in the Williams Fire plume since the Yucatan observations were made in the tropical boundary layer where most of the global smoke evolution occurs. However, the difference in OA evolution between the Yucatan and Williams Fire plume presents an opportunity to better understand the factors controlling $\mathrm{OA}$ evolution in smoke plumes. Here, we propose that the different balance between evaporation and condensation in the Yucatan plume and the Williams Fire plume could be rooted partly in the respective ambient conditions. In the case of the Williams Fire, the smoke penetrated above the boundary layer and diluted in the free troposphere where there was low RH $(\sim 11-26 \%$, Table 1). In the Yucatan, the plume diluted in the boundary layer at $70-100 \% \mathrm{RH}$, where particles would be more likely to have thick aqueous coatings. Hennigan et al. (2008) 
found that particle water soluble organic carbon (WSOC, a surrogate for SOA) may substantially increase upon reaching a threshold $\mathrm{RH}$ of $\sim 70 \%$ (though particle liquid water content may be strongly affected by particle hygroscopicity and not just RH). Furthermore, aqueous phase SOA formation results in a higher OA/OC ratio than straight gas-phase SOA formation and the high OA/OC in the Yucatan plume is consistent with some of the SOA being formed in the aqueous phase (Lim et al., 2010; Yokelson et al., 2009). The concentration of the hydroxyl radical in the plume should also affect how fast the gas-phase organic precursors for SOA are oxidized. In the Yucatan plume, the measured $\mathrm{OH}$ concentration was nearly twice our estimate of the $\mathrm{OH}$ in the Williams Fire plume. Both higher $\mathrm{OH}$ and the higher light intensity expected for the tropical (Yucatan) plume should speed up SOA formation in both the gas phase and aqueous phase. This speculation is further supported when comparing the rate of ozone formation: $\Delta \mathrm{O}_{3} / \Delta \mathrm{CO}$ increased $\sim 4$ times faster in the Yucatan plume than in the Williams Fire plume (Sect. 3.2.1). Thus, conditions in the Yucatan were significantly more favorable for the formation of SOA.

We have not ruled out the possibility that the different OA evolution observed between the Williams Fire and Yucatan plumes could be partly due to the different fuels and/or different volatilities of the initial POA. In a laboratory study of aging BB smoke Hennigan et al. (2011) observed the most SOA formation (growth factor of almost three) for black spruce fuel and minimal SOA formation for white spruce fuel. Thus, nominally similar fuels sometimes gave widely different outcomes in an experiment where the environmental variables were monitored, but not fixed to a narrow range. In assessing global SOA production from biomass burning it may be significant that the Yucatan plume evolved under conditions with more light, more $\mathrm{OH}$, and more chemical pathways for SOA formation than the Williams Fire plume and substantially more SOA was formed. Finally, we point out that the large increase in light scattering with plume age observed in both the Williams Fire and Yucatan plumes has important implications for visibility impacts and climate forcing regardless of the underlying mechanism (McMeeking et al., 2006; Reid et al., 2005a). More research would be useful to determine if the optical properties of moderately aged smoke are better suited for assessing the visibility and climate impacts of biomass burning.

\subsection{Evolution of the black carbon mixing state}

A fraction of $0.54 \pm 0.07$ of the initially emitted $\mathrm{rBC}$ particles are "thickly coated" as shown in Fig. 12 (solid circle, see Table 2). The remaining particles are classified as either "thinly coated" or "not coated" at the time of emission. However, the fraction of thickly coated (fTC) particles grew quickly and a fraction of $\sim 0.70 \pm 0.10$ of $\mathrm{rBC}$ particles were thickly coated within the first hour following emission. The fraction of thickly coated $\mathrm{rBC}$ particles for both

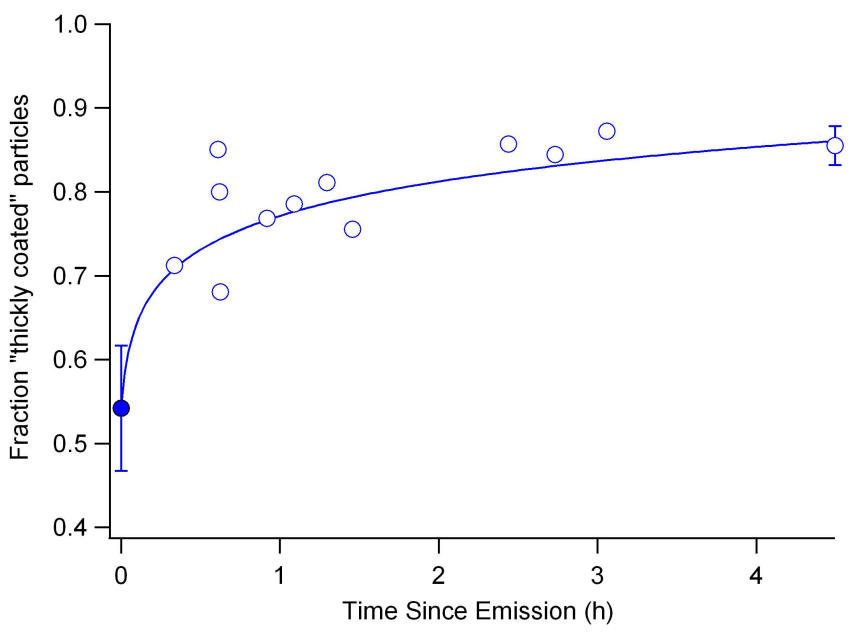

Fig. 12. Fraction of "thickly coated" (fTC) rBC particles vs. time since emission (h). Individual source sample fTC fractions are not shown and we instead show the mean fraction of source samples at $t=0 \mathrm{~h}$ (solid circle) with an error bar reflecting the standard deviation of the mean. The downwind error bar is an estimate of the uncertainty in the oldest individual downwind sample. Points were fit to a logarithmic trendline.

the fresh and $1 \mathrm{~h}$ old emissions was higher than in SP2 measurements from urban sources and the rate of increase in the Williams Fire plume was also faster than was observed in those urban plumes (McMeeking et al., 2011b). Schwarz et al. (2008) also found a higher fraction of rBC particles were thickly coated in BB plumes when compared to urban plumes that they measured nearby. Kondo et al. (2011) used an alternative analysis to show that $\mathrm{rBC}$ coatings in boreal $\mathrm{BB}$ plumes increased over several days, in some cases leading to increases in the volume of the coatings by a factor of two.

Similar coating development most likely also occurs on the nascent inorganic and organic particles. The coating formation on the rBC particles (a flaming product) likely formed in large part due to coagulation with OA particles produced by smoldering combustion. In addition, since ammonium and nitrate exhibit rapid initial increases, the coatings likely contain some inorganic material from gas-particle conversion involving precursors produced both by flaming $\left(\mathrm{NO}_{\mathrm{x}}\right)$ and smoldering $\left(\mathrm{NH}_{3}\right)$. Kondo et al. (2011) speculated that $\mathrm{OA}$ could be redistributed from non-rBC-containing particles as the plume aged through evaporation and recondensation and they also showed that coagulation alone can lead to substantial increases in $\mathrm{rBC}$ coatings.

Regardless of the exact mechanism, as the rBC (and other) particles become coated they may scatter light more efficiently due mostly to size increases, but also due to changes in the index of refraction of the particle surface layer. Thus, the observed increase in $\mathrm{rBC}$ coatings is consistent with the observed increase in $\Delta$ light scattering $/ \Delta \mathrm{CO}_{2}$ (Sect. 3.3). The evolution of the $\mathrm{BC}$ mixing state is also important 
because the addition of organic coatings can increase the mass absorption efficiency of the $\mathrm{BC}$ particles, though the magnitude of this effect may be lower if the coatings absorb light (Lack and Cappa, 2010). In addition, coating formation with salts and soluble organics increases the hygroscopicity of the particles (Petters et al., 2009; McMeeking et al., 2011a; Zhang et al., 2008) and this likely increases their contribution to indirect effects on clouds (Koch et al., 2011) as well as decreasing their lifetime and availability for long range transport to sensitive snow/ice covered regions (Petters et al., 2009). Finally, black carbon affects human health and visibility, and contributes both to warming due to its ability to absorb light and decrease surface albedo (Ramanathan and Carmichael, 2008), and cooling due to indirect effects on clouds (Koch et al., 2011). Our observations in the Williams Fire plume suggest that the evolution of the $\mathrm{BC}$ mixing state could significantly affect the overall impact of black carbon emitted by biomass fires.

\subsection{Dispersion of the low altitude plume}

Our measurements of the high-altitude $(1200-1900 \mathrm{~m}$ a.m.s.l.) plume generated by the Williams Fire detail the evolution of the bulk of the emissions produced by the fire and these emissions would contribute to the burden on the regional air shed along with many other sources. As discussed earlier (Sect. 2.2); a small fraction of the smoke from the Williams Fire detrained below $600 \mathrm{~m}$ a.m.s.l., drifted southeast, and settled into low lying areas (Fig. 2). We observed that this smoke was noticeably whiter in color and was probably more dominated by smoldering emissions, which implies a significant difference in chemical composition (Bertschi et al., 2003). Flight safety considerations prevented us from sampling this low-lying smoke. Thus, we examined data collected by county health departments (http://www.arb.ca. gov/aqmis2/aqdselect.php) for possible signatures of the low altitude Williams Fire plume. The nearest air quality station southeast of the Williams Fire was in Santa Ynez, but only $\mathrm{O}_{3}$ was monitored there and no clear influence of the Williams Fire was evident. The next closest station was in Santa Barbara where $\mathrm{PM}_{10}, \mathrm{PM}_{2.5}$, and $\mathrm{O}_{3}$ were monitored. A possible influence of the Williams Fire low-altitude plume was evident only in the nighttime $\mathrm{PM}_{2.5}$ maxima; which were 20,29 , and $13 \mu \mathrm{g} \mathrm{m}^{-3}$ for 16,17 , and 18 November, respectively. The modest increase in $\mathrm{PM}_{2.5}$ the night after the Williams Fire (17 November) may have been partly attributable to the fire, but the peak was below the air quality standard. In contrast, an extreme peak in $\mathrm{PM}_{10}\left(118 \mu \mathrm{g} \mathrm{m}^{-3}\right)$ on the night of 18 November that was not accompanied by an increase in $\mathrm{PM}_{2.5}$ was almost certainly due to noncombustion sources. A comprehensive network of groundbased samplers would have been needed to quantify the dispersion and chemistry of the low-altitude smoke and determine the contribution of the Williams Fire to pollution levels on the ground. The expected post-emission transport of smoke is already a critical factor when choosing prescribed burn locations and times in the US (Hardy et al., 2001). This case study illustrates that air quality predictions could benefit from research that elucidates both the rate of smoke production and the distribution of injection altitudes as a function of time.

\section{Conclusions}

In this work we describe detailed pseudo-Lagrangian measurements of the chemical evolution of an isolated biomass burning plume generated by a prescribed fire in a temperate chaparral ecosystem. Despite occurring approximately one month before the winter solstice, the plume was photochemically active and significant amounts of ozone formed within a few hours. Rapid formation of organic acids was also observed with the precursors likely being unidentified NMOC species. The measured decay in ethylene was consistent with an in-plume average $\mathrm{OH}$ of $5.27( \pm 0.97) \times 10^{6} \mathrm{molec} \mathrm{cm}^{-3}$. This is a factor of two or more lower $\mathrm{OH}$ than some observations in tropical BB plumes, but sufficiently high to affect large changes in plume chemistry within several hours. The calculated loss of $\mathrm{NO}_{\mathrm{x}}$ due to the reaction of $\mathrm{NO}_{2}$ with $\mathrm{OH}(\sim 54 \%)$ and the observed formation of PAN $(22 \pm 6 \%$ of initial $\mathrm{NO}_{\mathrm{x}}$ ) accounted for all the observed $\mathrm{NO}_{\mathrm{x}}$ loss $(80 \pm 10 \%)$ within the measurement uncertainty. Roughly half of the gas-phase $\mathrm{NH}_{3}$ was also lost within the $4 \mathrm{~h}$ since emission. While both particle ammonium and nitrate increased rapidly in the aging plume, the amount of the increase was significantly smaller than that required to balance the loss of the associated gas-phase precursors. We speculate that much of the "missing" ammonium and nitrate could have been present in small particles that grew slowly due to the low RH (11-26\%) and were thus too small to be detected efficiently by the AMS. In addition, a charge balance suggests that perhaps $\sim 40 \%$ of the ammonium was pairing with organic anions that were also not measured. In contrast to the rapid initial growth in some particle inorganic species, evaporation of OA dominated condensation for the first $1.5-2 \mathrm{~h}$ since emission. Thereafter OA increased slowly, but overall $\Delta \mathrm{OA} / \Delta \mathrm{CO}_{2}$ decreased by a factor of $0.80 \pm 0.21$ over $4 \mathrm{~h}$. In contrast, in an isolated tropical BB plume, rapid SOA formation was observed. We speculate that drivers for the higher SOA formation in the tropical plume include: higher $\mathrm{OH}$, higher incident UV radiation, and higher RH (70-100\%) where the latter would promote more SOA formation pathways. The sum of the excess values of the species measured by the AMS normalized to excess $\mathrm{CO}_{2}$ decreased slightly over $4 \mathrm{~h}$, suggesting a net loss of particulate matter. However, $\Delta$ light scattering $/ \Delta \mathrm{CO}_{2}$ increased by a factor of $\sim 2.50$ over $4 \mathrm{~h}$, which may have been due to mostly to rapid, initial coagulation-induced increases in particle diameter. The increase in scattering has implications for climate forcing and visibility even if it accompanied a decrease in particulate 
matter. We found that as much as $85 \%$ of the $\mathrm{BC}$ particles may have been thickly coated after $4 \mathrm{~h}$ following emission; most likely with a mix of organic and inorganic species. The coatings are likely to strongly influence the $\mathrm{BC}$ radiative forcing, increase the $\mathrm{BC}$ hygroscopicity and cloud impacts, and reduce the $\mathrm{BC}$ lifetime.

\section{Supplementary material related to this article is available online at: \\ http://www.atmos-chem-phys.net/12/1397/2012/ acp-12-1397-2012-supplement.pdf.}

Acknowledgements. We thank our pilot Scott Miller and the USFS Region 4 Twin Otter management and support team. We thank Jason McCarty and the Santa Barbara County Fire Department for carrying out the burn, fuels and weather information, and coordination with our airborne team. We thank Jose Jimenez, Doug Worsnop, and Chuck Kolb for useful discussions regarding this manuscript and Holly Eissinger for help in preparation of selected figures. Satellite imagery and analysis were provided by Mark Ruminski, NESDIS, Satellite Analysis Branch. Research modifications to the Twin Otter, specialized inlets, and upgrades to AFTIR were funded by NSF grant ATM-0513055. S. A., G. M., and R. Y. were supported in whole or part by NSF grant ATM-0936321. R. Y., J. C., I. B., and the Twin Otter flight hours were supported by the Strategic Environmental Research and Development Program (SERDP) projects SI-1648 and SI-1649 and administered through Forest Service Research Joint Venture Agreement 08JV11272166039, and we thank the sponsors for their support. Participation of the SP2 was made possible in part by a travel grant from the Royal Society and support from the UK Natural Environment Research Council.

Edited by: R. Cohen

\section{References}

Akagi, S. K., Yokelson, R. J., Wiedinmyer, C., Alvarado, M. J., Reid, J. S., Karl, T., Crounse, J. D., and Wennberg, P. O.: Emission factors for open and domestic biomass burning for use in atmospheric models, Atmos. Chem. Phys., 11, 4039-4072, doi:10.5194/acp-11-4039-2011, 2011.

Allan, J. D., Delia, A. E., Coe, H., Bower, K. N., Alfarra, M. R., Jimenez, J. L., Middlebrook, A. M., Drewnick, F., Onasch, T. B., Canagaratna, M. R., Jayne, J. T., and Worsnop, D. R.: A generalized method for the extraction of chemically resolved mass spectra from Aerodyne aerosol mass spectrometer data, J. Aerosol Sci., 35, 909-922, 2004.

Alvarado, M. J. and Prinn, R. G.: Formation of ozone and growth of aerosols in young smoke plumes from biomass burning: 1. Lagrangian parcel studies, J. Geophys. Res., 114, D09306, doi:10.1029/2008JD011144, 2009.

Alvarado, M. J., Logan, J. A., Mao, J., Apel, E., Riemer, D., Blake, D., Cohen, R. C., Min, K.-E., Perring, A. E., Browne, E. C., Wooldridge, P. J., Diskin, G. S., Sachse, G. W., Fuelberg, H.,
Sessions, W. R., Harrigan, D. L., Huey, G., Liao, J., Case-Hanks, A., Jimenez, J. L., Cubison, M. J., Vay, S. A., Weinheimer, A. J., Knapp, D. J., Montzka, D. D., Flocke, F. M., Pollack, I. B., Wennberg, P. O., Kurten, A., Crounse, J., Clair, J. M. St., Wisthaler, A., Mikoviny, T., Yantosca, R. M., Carouge, C. C., and Le Sager, P.: Nitrogen oxides and PAN in plumes from boreal fires during ARCTAS-B and their impact on ozone: an integrated analysis of aircraft and satellite observations, Atmos. Chem. Phys., 10, 9739-9760, doi:10.5194/acp-10-9739-2010, 2010.

Asman, W. A. H., Sutton, M. A., and Schjorring, J. K.: Ammonia: emission, atmospheric transport and deposition, New Phytol., 139, 27-48, 1998.

Bae, M.-S., Schwab, J. J., Zhang, Q., Hogrefe, O., Demerjian, K. L., Weimer, S., Rhoads, K., Orsini, D., Venkatachari, P., and Hopke, P. K.: Interference of organic signals in highly time resolved nitrate measurements by low mass resolution aerosol mass spectrometry, J. Geophys. Res., 112, D22305, doi:10.1029/2007JD008614, 2007.

Bertschi, I. T., Yokelson, R. J., Ward, D. E., Babbitt, R. E., Susott, R. A., Goode, J. G., and Hao, W. M.: Trace gas and particle emissions from fires in large diameter and belowground biomass fuels, J. Geophys. Res., 108, 8472, doi:10.1029/2002JD002100, 2003.

Beswick, K. M., Gallagher, M. W., Webb, A. R., Norton, E. G., and Perry, F.: Application of the Aventech AIMMS20AQ airborne probe for turbulence measurements during the Convective Storm Initiation Project, Atmos. Chem. Phys., 8, 5449-5463, doi:10.5194/acp-8-5449-2008, 2008.

Biswell, H.: Prescribed Burning in California Wildlands Vegetation Management, University of California Press, 1989.

Bond, T. C., Streets, D. G., Yarber, K. F., Nelson, S. M., Woo, J.H., and Klimont, Z.: A technology-based global inventory of black and organic carbon emissions from combustion, J. Geophys. Res., 109, D14203, doi:10.1029/2003JD003697, 2004.

Burling, I. R., Yokelson, R. J., Griffith, D. W. T., Johnson, T. J., Veres, P., Roberts, J. M., Warneke, C., Urbanski, S. P., Reardon, J., Weise, D. R., Hao, W. M., and de Gouw, J.: Laboratory measurements of trace gas emissions from biomass burning of fuel types from the southeastern and southwestern United States, Atmos. Chem. Phys., 10, 11115-11130, doi:10.5194/acp10-11115-2010, 2010.

Burling, I. R., Yokelson, R. J., Akagi, S. K., Urbanski, S. P., Wold, C. E., Griffith, D. W. T., Johnson, T. J., Reardon, J., and Weise, D. R.: Airborne and ground-based measurements of the trace gases and particles emitted by prescribed fires in the United States, Atmos. Chem. Phys., 11, 12197-12216, doi:10.5194/acp11-12197-2011, 2011.

Byun, D. and Schere, K. L.: Review of the governing equations, computational algorithms, and other components of the Models3 Community Multiscale Air Quality (CMAQ) modeling system, Appl. Mech. Rev., 59, 51-77, doi:10.1115/1.2128636, 2006.

Canagaratna, M. R., Jayne, J. T., Jimenez, J. L., Allan, J. D., Alfarra, M. R., Zhang, Q., Onasch, T. B., Drewnick, F., Coe, H., Middlebrook, A., Delia, A., Williams, L. R., Trimborn, A. M., Northway, M. J., DeCarlo, P. F., Kolb, C. E., Davidovits, P., and Worsnop, D. R.: Chemical and microphysical characterization of ambient aerosols with the Aerodyne aerosol mass spectrometer, edited by: Viggiano, A., Mass Spectrom. Rev., 26, 185-222, 
2007.

Capes, G., Murphy, J. G., Reeves, C. E., McQuaid, J. B., Hamilton, J. F., Hopkins, J. R., Crosier, J., Williams, P. I., and Coe, H.: Secondary organic aerosol from biogenic VOCs over West Africa during AMMA, Atmos. Chem. Phys., 9, 3841-3850, doi:10.5194/acp-9-3841-2009, 2009.

Carter, M. C. and Foster, C. D.: Prescribed burning and productivity in southern pine forests: a review, Forest Ecol. Manag., 191, 185-197, doi:10.1016/j.foreco.2003.11.006, 2004.

Chakrabarty, R. K., Moosmuller, H., Garro, M. A., Arnott, W. P., Walker, J., Susott, R. A., Babbitt, R. E., Wold, C. E., Lincoln, E. N., and Hao, W. M.: Emissions from the laboratory combustion of wildland fuels: Particle morphology and size, J. Geophys. Res., 111, D07204, doi:10.1029/2005JD006659, 2006.

Cofer III., W. R., Levine, J. S., Riggan, P. J., Sebacher, D. I., Winstead, E. L., Shaw Jr., E. F., Brass, J. A., and Ambrosia, V. G.: Trace gas emissions from a mid-latitude prescribe chaparral fire, J. Geophys. Res., 93, 1653-1658, 1988.

Crutzen, P. J. and Andreae, M. O.: Biomass burning in the tropics: Impact on atmospheric chemistry and biogeochemical cycles, Science, 250, 1669-1678, 1990.

Cubison, M. J., Ortega, A. M., Hayes, P. L., Farmer, D. K., Day, D., Lechner, M. J., Brune, W. H., Apel, E., Diskin, G. S., Fisher, J. A., Fuelberg, H. E., Hecobian, A., Knapp, D. J., Mikoviny, T., Riemer, D., Sachse, G. W., Sessions, W., Weber, R. J., Weinheimer, A. J., Wisthaler, A., and Jimenez, J. L.: Effects of aging on organic aerosol from open biomass burning smoke in aircraft and laboratory studies, Atmos. Chem. Phys., 11, 12049-12064, doi:10.5194/acp-11-12049-2011, 2011.

De Gouw, J. and Jimenez, J. L.: Organic aerosols in the Earth's atmosphere, Environ. Sci. Technol., 43, 7614-7618, 2009.

Dentener, F. J. and Crutzen, P. J.: A three-dimensional model of the global ammonia cycle, J. Atmos. Chem., 19, 331-369, 1994.

Draxler, R. R. and Rolph, G. D.: HYSPLIT (HYbrid Single-Particle Lagrangian Integrated Trajectory) Model access via NOAA ARL READY Website: http://ready.arl.noaa.gov/HYSPLIT.php, last access: 4 August 2011, NOAA Air Resources Laboratory, Silver Spring, MD, 2010.

Drewnick, F., Schwab, J. J., Hogrefe, O., Peters, S., Husain, L., Diamond, D., Weber, R., and Demerjian, K. L.: Intercomparison and evaluation of four semi-continuous $\mathrm{PM}_{2.5}$ sulfate instruments, Atmos. Environ., 37, 3335-3350, 2003.

Drewnick, F., Hings, S. S., DeCarlo, P., Jayne, J. T., Gonin, M., Fuhrer, K., Weimer, S., Jimenez, J. L., Demerjian, K. L., Borrmann, S., and Worsnop, D. R.: A new Time-of-Flight Aerosol Mass Spectrometer (TOF-AMS) - instrument description and first field deployment, Aerosol Sci. Tech., 39, 637-658, 2005.

Ebeling, J. M. and Jenkins, B. M.: Physical and chemical properties of biomass fuels, T. ASAE, 28, 898-902, 1985.

Fearnside, P. M., Leal Jr., N., and Fernandes, F. M.: Rainforest burning and the global carbon budget: biomass, combustion efficiency, and charcoal formation in the Brazilian Amazon, J. Geophys. Res., 98, 16733-16743, 1993.

Ferek, R. J., Reid, J. S., Hobbs, P. V., Blake, D. R., and Liousse, C.: Emission factors of hydrocarbons, halocarbons, trace gases, and particles from biomass burning in Brazil, J. Geophys. Res., 103, 32107-32118, doi:10.1029/98JD00692, 1998.

Finlayson-Pitts, B. J. and Pitts Jr., J. N.: Chemistry of the Upper and Lower Atmosphere, Academic Press, San Diego, USA, 969 pp., 2000.

Fishman, J., Wozniak, A. E., and Creilson, J. K.: Global distribution of tropospheric ozone from satellite measurements using the empirically corrected tropospheric ozone residual technique: Identification of the regional aspects of air pollution, Atmos. Chem. Phys., 3, 893-907, doi:10.5194/acp-3-893-2003, 2003.

Goode, J. G., Yokelson, R. J., Susott, R. A., and Ward, D. E.: Trace gas emissions from laboratory biomass fires measured by openpath Fourier transform infrared spectroscopy: Fires in grass and surface fuels, J. Geophys. Res., 104, 21237-21245, 1999.

Grieshop, A. P., Logue, J. M., Donahue, N. M., and Robinson, A. L.: Laboratory investigation of photochemical oxidation of organic aerosol from wood fires 1: measurement and simulation of organic aerosol evolution, Atmos. Chem. Phys., 9, 1263-1277, doi:10.5194/acp-9-1263-2009, 2009

Griffith, D. W. T.: Synthetic calibration and quantitative analysis of gas-phase FTIR spectra, Appl. Spectrosc., 50, 59-70, 1996.

Haines, T. K. and Cleaves, D. A.: The legal environment for forestry prescribed burning in the south: Regulatory programs and voluntary guidelines, South J. Appl. For., 23, 170-74, 1999.

Hardy, C. C. and Teesdale, D. R.: Source characterization and control of smoke emissions from prescribed burning of California chaparral, CDF Contract No. 89CA96071, California Department of Forestry and Fire Protection, Sacramento, CA, 1991.

Hardy, C. C., Conard, S. G., Regelbrugge, J. C., and Teesdale, D. R.: Smoke emissions from prescribed burning of southern California chaparral, Res. Pap. PNW-RP-486, US Department of Agriculture, Forest Service, Pacific Northwest Research Station, Portland, OR, 1996.

Hardy, C. C., Ottmar, R. D., Peterson, J. L., Core, J. E., and Seamon, P.: Smoke management guide for prescribed and wildland fire: 2001 edition, available at: http://www.treesearch.fs.fed.us/pubs/ 5388, last access: 4 August 2011, National Wildfire Coordination Group, Boise, ID, 2001.

Heald, C. L., Jacob, D. J., Park, R. J., Russell, L. M., Huebert, B. J., Seinfeld, J. H., Liao, H., and Weber, R. J.: A large organic aerosol source in the free troposphere missing from current models, Geophys. Res. Lett., 32, L18809, doi:10.1029/2005GL023831, 2005.

Hennigan, C. J., Bergin, M. H., Dibb, J. E., and Weber, R. J.: Enhanced secondary organic aerosol formation due to water uptake by fine particles, Geophys. Res. Lett., 35, L18801, doi:10.1029/2008GL035046, 2008.

Hennigan, C. J., Miracolo, M. A., Engelhart, G. J., May, A. A., Presto, A. A., Lee, T., Sullivan, A. P., McMeeking, G. R., Coe, H., Wold, C. E., Hao, W.-M., Gilman, J. B., Kuster, W. C., de Gouw, J., Schichtel, B. A., J. L. Collett Jr., Kreidenweis, S. M., and Robinson, A. L.: Chemical and physical transformations of organic aerosol from the photo-oxidation of open biomass burning emissions in an environmental chamber, Atmos. Chem. Phys., 11, 7669-7686, doi:10.5194/acp-11-7669-2011, 2011

Heringa, M. F., DeCarlo, P. F., Chirico, R., Tritscher, T., Dommen, J., Weingartner, E., Richter, R., Wehrle, G., Prévôt, A. S. H., and Baltensperger, U.: Investigations of primary and secondary particulate matter of different wood combustion appliances with a high-resolution time-of-flight aerosol mass spectrometer, Atmos. Chem. Phys., 11, 5945-5957, doi:10.5194/acp-11-59452011, 2011. 
Hobbs, P. V., Reid, J. S., Herring, J. A., Nance, J. D. Weiss, R. E., Ross, J. L., Hegg, D. A., Ottmar, R. D., and Liousse, C.: Particle and trace-gas measurements in the smoke from prescribed burns of forest products in the Pacific northwest, in: Biomass Burning and Global Change, vol. 2, edited by: Levine, J. S., MIT Press, Cambridge, Mass., 697-715, 1996.

Hobbs, P. V., Sinha, P., Yokelson, R. J., Christian, T. J., Blake, D. R., Gao, S., Kirchstetter, T. W., Novakov, T., and Pilewskie, P.: Evolution of gases and particles from a savanna fire in South Africa, J. Geophys. Res., 108, 8485, doi:10.1029/2002JD002352, 2003.

Hosseini, S., Li, Q., Cocker, D., Weise, D., Miller, A., Shrivastava, M., Miller, J. W., Mahalingam, S., Princevac, M., and Jung, H.: Particle size distributions from laboratory-scale biomass fires using fast response instruments, Atmos. Chem. Phys., 10, 80658076, doi:10.5194/acp-10-8065-2010, 2010.

Huffman, J. A., Jayne, J. T., Drewnick, F., Aiken, A. C., Onasch, T., Worsnop, D. R., and Jimenez, J. L.: Design, modeling, optimization, and experimental tests of a particle beam width probe for the aerodyne aerosol mass spectrometer, Aerosol Sci. Technol., 39, 1143-1163, 2005.

Huffman, J. A., Docherty, K. S., Aiken, A. C., Cubison, M. J., U1brich, I. M., DeCarlo, P. F., Sueper, D., Jayne, J. T., Worsnop, D. R., Ziemann, P. J., and Jimenez, J. L.: Chemically-resolved aerosol volatility measurements from two megacity field studies, Atmos. Chem. Phys., 9, 7161-7182, doi:10.5194/acp-9-71612009, 2009.

Johnson, T. J., Masiello, T., and Sharpe, S. W.: The quantitative infrared and NIR spectrum of $\mathrm{CH}_{2} \mathrm{I}_{2}$ vapor: vibrational assignments and potential for atmospheric monitoring, Atmos. Chem. Phys., 6, 2581-2591, doi:10.5194/acp-6-2581-2006, 2006.

Johnson, T. J., Profeta, L. T. M., Sams, R. L., Griffith, D. W. T., and Yokelson, R. J.: An infrared spectral database for detection of gases emitted by biomass burning, Vib. Spectrosc., 53, 97-102, 2010.

Karl, T. G., Christian, T. J., Yokelson, R. J., Artaxo, P., Hao, W. M., and Guenther, A.: The Tropical Forest and Fire Emissions Experiment: method evaluation of volatile organic compound emissions measured by PTR-MS, FTIR, and GC from tropical biomass burning, Atmos. Chem. Phys., 7, 5883-5897, doi:10.5194/acp-7-5883-2007, 2007.

Kauffman, J. B.: Death rides the forest: perceptions of fire, land use, and ecological restoration of western forests, Conserv. Biol., 18, 878-882, 2004.

Koch, D., Balkanski, Y., Bauer, S. E., Easter, R. C., Ferrachat, S., Ghan, S. J., Hoose, C., Iversen, T., Kirkevåg, A., Kristjansson, J. E., Liu, X., Lohmann, U., Menon, S., Quaas, J., Schulz, M., Seland, Ø., Takemura, T., and Yan, N.: Soot microphysical effects on liquid clouds, a multi-model investigation, Atmos. Chem. Phys., 11, 1051-1064, doi:10.5194/acp-11-1051-2011, 2011.

Kondo, Y., Matsui, H., Moteki, N., Sahu, L., Takegawa, N., Kajino, M., Zhao, Y., Cubison, M. J., Jimenez, J. L., Vay, S., Diskin, G. S., Anderson, B., Wisthaler, A., Mikoviny, T., Fuelberg, H. E., Blake, D. R., Huey, G., Weinheimer, A. J., Knapp, D. J., and Brune, W. H.: Emissions of black carbon, organic, and inorganic aerosols from biomass burning in North America and Asia in 2008, J. Geophys. Res., 116, D08204, doi:10.1029/2010JD015152, 2011.

Lack, D. A. and Cappa, C. D.: Impact of brown and clear carbon on light absorption enhancement, single scatter albedo and ab- sorption wavelength dependence of black carbon, Atmos. Chem. Phys., 10, 4207-4220, doi:10.5194/acp-10-4207-2010, 2010.

Lee, S., Baumann, K., Schauer, J. J., Sheesley, R. J., Naeher, L. P., Meinardi, S., Blake, D. R., Edgerton, E. S., Russell, A. G., and Clements, M.: Gaseous and particulate emissions from prescribed burning in Georgia, Environ. Sci. Technol., 39, 9049 9056, 2005.

Li, J., Posfai, M., Hobbs, P. V., and Buseck, P. R.: Individual aerosol particles from biomass burning in southern Africa: 2. Compositions and aging of inorganic particles, J. Geophys. Res., 108, 8484, doi:10.1029/2002JD002310, 2003.

Lim, Y. B., Tan, Y., Perri, M. J., Seitzinger, S. P., and Turpin, B. J.: Aqueous chemistry and its role in secondary organic aerosol (SOA) formation, Atmos. Chem. Phys., 10, 1052110539, doi:10.5194/acp-10-10521-2010, 2010.

Mason, S. A., Field, R. J., Yokelson, R. J., Kochivar, M. A., and Tinsley, M. R.: Complex effects arising in smoke plume simulations due to inclusion of direct emissions of oxygenated organic species from biomass combustion, J. Geophys. Res., 106, 1252712539, 2001.

McMeeking, G. R., Kreidenweis, S. M., Lunden, M., Carrillo, J., Carrico, C. M., Lee, T., Herckes, P., Engling, G., Day, D. E., Hand, J., Brown, N., Malm, W. C., and Collett Jr., J. L.: Smokeimpacted regional haze in California during the summer of 2002, Agr. Forest Meteorol., 137, 25-42, 2006.

McMeeking, G. R., Kreidenweis, S. M., Baker, S., Carrico, C. M., Chow, J. C., Collet Jr., J. L., Hao, W. M., Holden, A. S., Kirchstetter, T. W., Malm, W. C., Moosmüller, H., Sullivan, A. P., and Wold, C. E.: Emissions of trace gases and aerosols during the open combustion of biomass in the laboratory, J. Geophys. Res., 114, D19210, doi:10.1029/2009JD011836, 2009.

McMeeking, G. R., Good, N., Petters, M. D., McFiggans, G., and Coe, H.: Influences on the fraction of hydrophobic and hydrophilic black carbon in the atmosphere, Atmos. Chem. Phys., 11, 5099-5112, doi:10.5194/acp-11-5099-2011, 2011 a.

McMeeking, G. R., Morgan, W. T., Flynn, M., Highwood, E. J., Turnbull, K., Haywood, J., and Coe, H.: Black carbon aerosol mixing state, organic aerosols and aerosol optical properties over the United Kingdom, Atmos. Chem. Phys., 11, 9037-9052, doi:10.5194/acp-11-9037-2011, $2011 \mathrm{~b}$.

Moteki, N. and Kondo, Y.: Effects of mixing state of black carbon measurements by laser-induced incandescence, Aerosol Sci. Tech., 41, 398-417, 2007.

Mühle, J., Lueker, T. J., Su, Y., Miller, B. R., Prather, K. A., and Weiss, R. F.: Trace gas and particulate emissions from the 2003 southern California wildfires, J. Geophys. Res., 112, D03307, doi:10.1029/2006JD007350, 2007.

Park, R. J., Jacob, D. J., and Logan, J. A.: Fire and biofuel contributions to annual mean aerosol concentrations in the United States, Atmos. Environ., 41, 7389-7400, 2007.

Perri, M. J., Seitzinger, S., and Turpin, B. J.: Secondary organic aerosol production from aqueous photooxidation of glycolaldehyde: Laboratory experiments, Atmos. Environ., 43, 1487-1497, 2009.

Petters, M. D., Carrico, C. M., Kreidenweis, S. M., Prenni, A. J., DeMott, P. J., Collett, J. L., and Moosmüller, H.: Cloud condensation nucleation activity of biomass burning aerosol, J. Geophys. Res., 114, D22205, doi:10.1029/2009jd012353, 2009.

Pfister, G. G., Emmons, L. K., Hess, P. G., Honrath, R., Lamarque, 
J.-F., Val Martin, M., Owen, R. C., Avery, M. A., Browell, E. V., Holloway, J. S., Nedelec, P., Purvis, R., Ryerson, T. B., Sachse, G. W., and Schlager, H.: Ozone production from the 2004 North American boreal fires, J. Geophys. Res., 111, D24S07, doi:10.1029/2006JD007695, 2006.

Phuleria, H. C., Sheesley, R. J., Schauer, J. J., Fine, P. M., and Sioutas, C.: Roadside measurements of size-segregated particulate organic compounds near gasoline and diesel-dominated freeways in Los Angeles, CA, Atmos. Environ., 41, 4653-4671, 2007.

Posfai, M., Simonics, R., Li, J., Hobbs, P. V., and Buseck, P. R.: Individual aerosol particles from biomass burning in southern Africa: 1. Compositions and size distributions of carbonaceous particles, J. Geophys. Res., 108, 8483, doi:10.1029/2002JD002291, 2003.

Radke, L. F., Lyons, J. H., Hobbs, P. V., Hegg, D. A., Sandberg, D. V., and Ward, D. E.: Airborne monitoring and smoke characterization of prescribed fires on forest lands in western Washington and Oregon, Gen. Tech. Rep. PNW-GTR-251, Portland, OR, US, Dept. of Agriculture, Forest Service, Pacific Northwest Research Station, 1990.

Radke, L. F., Hegg, D. A., Hobbs, P. V., Nance, J. D., Lyons, J. H., Laursen, K. K., Weiss, R. E., Riggan, P. J., and Ward, D. E.: Particulate and trace gas emissions from large biomass fires in North America, Global biomass burning - Atmospheric, climatic, and biospheric implications, MIT Press, Cambridge, MA, 209-224, 1991.

Radlein, D., Piskorz, J., and Scott, D. S.: Fast pyrolysis of natural polysaccharides as a potential industrial process, J. Anal. Appl. Pyrolysis, 19, 41-63, 1991.

Ramanathan, V. and Carmichael, G.: Global and regional climate changes due to black carbon, Nat. Geosci., 1, 221-227, doi:10.1038/ngeo156, 2008.

Reid, J. S., Hobbs, P. V., Ferek, R. J., Martins, J. V., Blake, D. R., Dunlap, M. R., and Liousse, C.: Physical, chemical, and radiative characteristics of the smoke dominated regional hazes over Brazil, J. Geophys. Res., 103, 32059-32080, 1998.

Reid, J. S., Eck, T. F., Christopher, S. A., Koppmann, R., Dubovik, O., Eleuterio, D. P., Holben, B. N., Reid, E. A., and Zhang, J.: A review of biomass burning emissions part III: intensive optical properties of biomass burning particles, Atmos. Chem. Phys., 5, 827-849, doi:10.5194/acp-5-827-2005, 2005a.

Reid, J. S., Koppmann, R., Eck, T. F., and Eleuterio, D. P.: A review of biomass burning emissions part II: intensive physical properties of biomass burning particles, Atmos. Chem. Phys., 5, 799825, doi:10.5194/acp-5-799-2005, 2005b.

Richards, G. N.: Glycolaldehyde from pyrolysis of cellulose, J. Anal. Appl. Pyrolysis, 10, 251-255, 1987.

Robinson, A. L., Donahue, N. M., Shrivastava, M. K., Weitkamp, E. A., Sage, A. M., Grieshop, A. P., Lane, T. E., Pierce, J. R., and Pandis, S. N.: Rethinking organic aerosols: Semivolatile emissions and photochemical aging, Science, 315, 1259-1262, 2007.

Rolph, G. D.: Real-time Environmental Applications and Display sYstem (READY) Website (http://ready.arl.noaa.gov, last access: 27 January 2012), NOAA Air Resources Laboratory, Silver Spring, MD, 2010.

Rothman, L. S., Gordon, I. E., Barbe, A., Benner, D. C., Bernath, P. F., Birk, M., Boudon, V., Brown, L. R., Campargue, A., Champion, J. P., Chance, K., Coudert, L. H., Dana, V., Devi,
V. M., Fally, S., Flaud, J. M., Gamache, R. R., Goldman, A., Jacquemart, D., Kleiner, I., Lacome, N., Lafferty, W. J., Mandin, J. Y., Massie, S. T., Mikhailenko, S. N., Miller, C. E., Moazzen-Ahmadi, N., Naumenko, O. V., Nikitin, A. V., Orphal, J., Perevalov, V. I., Perrin, A., Predoi-Cross, A., Rinsland, C. P., Rotger, M., Simecková, M., Smith, M. A. H., Sung, K., Tashkun, S. A., Tennyson, J., Toth, R. A., Vandaele, A. C., and Vander Auwera, J.: The HITRAN 2008 molecular spectroscopic database, J. Quant. Spectrosc. Ra., 110, 533-572, 2009.

Sandberg, D. V., Ottmar, R. D., Peterson, J. L., and Core, J.: Wildland fire on ecosystems: effects of fire on air, Gen. Tech. Rep. RMRS-GTR-42-vol. 5, Ogden, UT, US, Department of Agriculture, Forest Service, Rocky Mountain Research Station, 2002.

Sander, S. P., Finlayson-Pitts, B. J., Friedl, R. R., Golden, D. M., Huie, R. E., Keller-Rudek, H., Kolb, C. E., Kurylo, M. J., Molina, M. J., Moortgat, G. K., Orkin, V. L., Ravishankara, A. R., and Wine, P. W.: Chemical kinetics and photochemical data for use in atmospheric studies, Evaluation Number 15 (JPL Publication 06-2), Jet Propulsion Laboratory, Pasadena, CA, 2006.

Schwarz, J. P., Gao, R. S., Fahey, D. W., Thomson, D. S., Watts, L. A., Wilson, J. C., Reeves, J. M., Darbeheshti, M., Baumgardner, D. G., Kok, G. L., Chung, S. H., Schulz, M., Hendricks, J., Lauer, A., Karcher, B., Slowik, J. G., Rosenlof, K. H., Thompson, T. L., Langford, A. O., Loewenstein, M., and Aikin, K. C.: Single-particle measurements of midlatitude black carbon and light-scattering aerosols from the boundary layer to the lower stratosphere, J. Geophys. Res., 111, D16207, doi:10.1029/2006JD007076, 2006.

Schwarz, J. P., Gao, R. S., Spackman, J. R., Watts, L. A., Thomson, D. S., Fahey, D. W., Ryerson, T. B., Peischl, J., Holloway, J. S., Trainer, M., Frost, G. J., Baynard, T., Lack, D. A., de Gouw, J. A., Warneke, C., and Del Negro, L. A.: Measurement of the mixing state, mass, and optical size of individual black carbon particles in urban and biomass burning emissions, Geophys. Res. Lett., 35, L13810, doi:10.1029/2008GL033968, 2008.

Seinfeld, J. H. and Pandis, S. N.: Atmospheric chemistry and physics: From air pollution to climate change, John Wiley \& Sons, Inc., US, 2006.

Semuniuk, T. A., Wise, M. E., Martin, S. T., Russell, L. M., and Buseck, P. R.: Hygroscopic behavior of aerosol particles from biomass fires using environmental transmission electron microscopy, J. Atmos. Chem., 56, 259-273, 2007.

Sharpe, S. W., Johnson, T. J., Sams, R. L., Chu, P. M., Rhoderick, G. C., and Johnson, P. A.: Gas-phase databases for quantitative infrared spectroscopy, Appl. Spectrosc., 58, 1452-1461, 2004.

Shiraiwa, M., Kondo, Y., Moteki, N., Takegawa, N., Miyazaki, Y., and Blake, D. R.: Evolution of mixing state of black carbon in polluted air from Tokyo, Geophys. Res. Lett., 34, L16803, doi:10.1029/2007g1029819, 2007.

Stephens, M., Turner, N., and Sandberg, J.: Particle identification by laser-induced incandescence in a solid-state laser cavity, Appl. Opt., 42, 3726-3736, 2003.

Stephens, S. L., Martin, R. E., and Clinton, N. E.: Prehistoric fire area and emissions from California's forests, woodlands, shrublands, and grasslands, Forest Ecol. Manag., 251, 205-216, 2007.

Sudo, K. and Akimoto, H.: Global source attribution of tropospheric ozone: Long-range transport from various source regions, J. Geophys. Res., 112, D12302, doi:10.1029/2006JD007992, 2007. 
Susott, R. A., Olbu, G. J., Baker, S. P., Ward, D. E., Kauffman, J. B., and Shea, R. W.: Carbon, hydrogen, nitrogen, and thermogravimetric analysis of tropical ecosystem biomass, in: Biomass Burning and Global Change, edited by: Levine, J. S., MIT Press, Cambridge, 350-360, 1996.

Tabazadeh, A., Jacobson, M. Z., Singh, H. B., Toon, O. B., Lin, J. S., Chatfield, R. B., Thakur, A. N., Talbot, R. W., and Dibb, J. E.: Nitric acid scavenging by mineral and biomass burning aerosols, Geophys. Res. Lett., 25, 4185-4188, 1998.

Tabazadeh, A., Yokelson, R. J., Singh, H. B., Hobbs, P. V., Crawford, J. H., and Iraci, L. T.: Heterogeneous chemistry involving methanol in tropospheric clouds, Geophys. Res. Lett., 31, L06114, doi:10.1029/2003GL018775, 2004.

Tang, I. N. and Munkelwitz, H. R.: Composition and temperature dependence of the deliquescence properties of hygroscopic aerosols, Atmos. Environ., 27A, 467-473, 1993.

Tang, I. N. and Munkelwitz, H. R.: Water activities, densities, and refractive indices of aqueous sulfates and sodium nitrate droplets of atmospheric importance, J. Geophys. Res., 99, 18801-18808, 1994a.

Tang, I. N. and Munkelwitz, H. R.: Aerosol phase transformation and growth in the atmosphere, J. Appl. Meteorol., 33, 792-796, 1994b.

Trent, A., Davies, M. A., Fisher, R., Thistle, H., and Babbitt, R.: Evaluation of optical instruments for real-time, continuous monitoring of smoke particulates, Tech. Rep. 00252860 MTDC, USDA Forest Service, Missoula Technology and Development Center, Missoula, MT, USA, 38 pp., 2000.

Trentmann, J., Andreae, M. O., and Graf, H.-F.: Chemical processes in a young biomass-burning plume, J. Geophys. Res., 108, 4705, doi:10.1029/2003JD003732, 2003.

Trentmann, J., Yokelson, R. J., Hobbs, P. V., Winterrath, T., Christian, T. J., Andreae, M. O., and Mason, S. A.: An analysis of the chemical processes in the smoke plume from a savanna fire, J. Geophys. Res., 110, D12301, doi:10.1029/2004JD005628, 2005.

Val Martin, M., Honrath, R. E., Owen, R. C., Pfister, G., Fialho, P., and Barata, F.: Significant enhancements of nitrogen oxides, black carbon, and ozone in the North Atlantic lower free troposphere resulting from North American boreal wildfires, J. Geophys. Res., 111, D23S60, doi:10.1029/2006JD007530, 2006.

van der Werf, G. R., Randerson, J. T., Giglio, L., Collatz, G. J., Mu, M., Kasibhatla, P. S., Morton, D. C., DeFries, R. S., Jin, Y., and van Leeuwen, T. T.: Global fire emissions and the contribution of deforestation, savanna, forest, agricultural, and peat fires (19972009), Atmos. Chem. Phys., 10, 11707-11735, doi:10.5194/acp10-11707-2010, 2010.

Veres, P., Roberts, J. M., Burling, I. R., Warneke, C., de Gouw, J., and Yokelson, R. J.: Measurements of gas-phase inorganic and organic acids from biomass fires by negative-ion proton-transfer chemical-ionization mass spectrometry, J. Geophys. Res., 115, D23302, doi:10.1029/2010JD014033, 2010.

Ward, D. E., Peterson, J., and Hao, W. M.: An inventory of particulate matter and air toxic emissions from prescribed fires in the USA for 1989, Air and Waste Management Assoc. Annual Meeting, Denver, CO, 14-18 June 1993, 93-MP-6.04, 1993.

Warneke, C., Bahreini, R., Brioude, J., Brock, C. A., de Gouw, J. A., Fahey, D. W., Froyd, K. D., Holloway, J. S., Middlebrook, A., Miller, L., Montzka, S., Murphy, D. M., Peischl, J., Ryerson, T. B., Schwarz, J. P., Spackman, J. R., and Veres, P.: Biomass burning in Siberia and Kazakhstan as an important source for haze over the Alaskan Arctic in April 2008, Geophys. Res. Lett., 36, L02813, doi:10.1029/2008GL036194, 2009.

Warneke, C., Roberts, J. M., Veres, P., Gilman, J., Kuster, W. C., Burling, I., Yokelson, R. J., and de Gouw, J. A.: VOC identification and inter-comparison from laboratory biomass burning using PTR-MS and PIT-MS, Int. J. Mass Spectrom. Ion Proc., 303, 6-14, doi:10.1016/j.ijms.2010.12.002, 2011.

Watson, J. G.: Visibility: Science and regulation, J. Air Waste Manage., 52, 628-713, 2002.

Wiedinmyer, C. and Hurteau, M. D.: Prescribed fire as a means of reducing forest carbon emissions in the Western United States, Environ. Sci. Technol., 44, 1926-1932, 2010.

Yoder, J., Tilley, M., Engle, D., and Fuhlendorf, D.: Economics and prescribed fire law in the United States, Applied Economic Perspectives and Policy, 25, 218-233, doi:10.1111/14679353.00055, 2003.

Yokelson, R. J., Griffith, D. W. T., and Ward, D. E.: Open path Fourier transform infrared studies of large-scale laboratory biomass fires, J. Geophys. Res., 101, 21067-21080, doi:10.1029/96JD01800, 1996.

Yokelson, R. J., Ward, D. E., Susott, R. A., Reardon, J., and Griffith, D. W. T.: Emissions from smoldering combustion of biomass measured by open-path Fourier transform infrared spectroscopy, J. Geophys. Res., 102, 18865-18877, 1997.

Yokelson, R. J., Goode, J. G., Ward, D. E., Susott, R. A., Babbitt, R. E., Wade, D. D., Bertschi, I., Griffith, D. W. T., and Hao, W. M.: Emissions of formaldehyde, acetic acid, methanol, and other trace gases from biomass fires in North Carolina measured by airborne Fourier transform infrared spectroscopy, J. Geophys. Res., 104, 30109-30126, doi:10.1029/1999JD900817, 1999.

Yokelson, R. J., Bertschi, I. T., Christian, T. J., Hobbs, P. V., Ward, D. E., and Hao, W. M.: Trace gas measurements in nascent, aged, and cloud-processed smoke from African savanna fires by airborne Fourier transform infrared spectroscopy (AFTIR), J. Geophys. Res., 108, 8478, doi:10.1029/2002JD002322, 2003a.

Yokelson, R. J., Christian, T. J., Bertschi, I. T., and Hao, W. M.: Evaluation of adsorption effects on measurements of ammonia, acetic acid, and methanol, J. Geophys. Res., 108, 4649, doi:10.1029/2003JD003549, 2003b.

Yokelson, R. J., Karl, T., Artaxo, P., Blake, D. R., Christian, T. J., Griffith, D. W. T., Guenther, A., and Hao, W. M.: The Tropical Forest and Fire Emissions Experiment: overview and airborne fire emission factor measurements, Atmos. Chem. Phys., 7, 5175-5196, doi:10.5194/acp-7-5175-2007, 2007a.

Yokelson, R. J., Urbanski, S. P., Atlas, E. L., Toohey, D. W., Alvarado, E. C., Crounse, J. D., Wennberg, P. O., Fisher, M. E., Wold, C. E., Campos, T. L., Adachi, K., Buseck, P. R., and Hao, W. M.: Emissions from forest fires near Mexico City, Atmos. Chem. Phys., 7, 5569-5584, doi:10.5194/acp-7-5569-2007, 2007b.

Yokelson, R. J., Crounse, J. D., DeCarlo, P. F., Karl, T., Urbanski, S., Atlas, E., Campos, T., Shinozuka, Y., Kapustin, V., Clarke, A. D., Weinheimer, A., Knapp, D. J., Montzka, D. D., Holloway, J., Weibring, P., Flocke, F., Zheng, W., Toohey, D., Wennberg, P. O., Wiedinmyer, C., Mauldin, L., Fried, A., Richter, D., Walega, J., Jimenez, J. L., Adachi, K., Buseck, P. R., Hall, S. R., and Shetter, R.: Emissions from biomass burning in the Yucatan, Atmos. Chem. Phys., 9, 5785-5812, doi:10.5194/acp-9-5785-2009, 
2009.

Zhang, R. Y., Khalizov, A. F., Pagels, J., Zhang, D., Xue, H., and McMurry, P. H.: Variability in morphology, hygroscopicity, and optical properties of soot aerosols during atmospheric processing, P. Natl. Acad. Sci. USA, 105, 10291-10296, 2008.
Zhang, X., Hecobian, A., Zheng, M., Frank, N. H., and Weber, R. J.: Biomass burning impact on $\mathrm{PM}_{2.5}$ over the southeastern US during 2007: integrating chemically speciated FRM filter measurements, MODIS fire counts and PMF analysis, Atmos. Chem. Phys., 10, 6839-6853, doi:10.5194/acp-10-6839-2010, 2010. 